\title{
Földtani objektumok értékminősítése: módszertani értékelés a védelem, bemutatás, fenntarthatóság és a geoturisztikai fejlesztések tükrében
}

\author{
SzEPESI János ${ }^{1}$, ÉsIK Zsuzsanna ${ }^{2}$, Soós Ildikó ${ }^{1}$, NovÁK Tibor ${ }^{3}$, SÜTő Lászlót ${ }^{4}$, RózSA Péter ${ }^{2}$, LuKÁcs Réka ${ }^{1}$, \\ HARANGI Szabolcs ${ }^{1}$ \\ ${ }^{1}$ MTA-ELTE Vulkanológiai Kutatócsoport 1117 Budapest Pázmány Péter sétány 1/C \\ ${ }^{2}$ Debreceni Egyetem Ásvány- és Földtani Tanszék 4010 Debrecen Egyetem tér 1. \\ ${ }^{3}$ Debreceni Egyetem Tájvédelmi és Környezetföldrajzi Tanszék, 4010 Debrecen, Egyetem tér 1. \\ ${ }^{4}$ Eszterházi Károly Egyetem Természetföldrajzi és Geoinformatikai Tanszék
}

\section{Methodological review of geosite inventory and assessment work in the light of protection, sustainability and the development of geotourism}

Abstract

The concept of geodiversity involving abiotic elements of the environment arose as a scientific topic in the last decade of the $20^{\text {th }}$ century. The increasing number of geological exhibition sites and the public interest in the two domestic UNESCO Global Geoparks in Hungary (Novohrad-Nógrád, Bakony-Balaton) indicated that geodiversity-based geotourism had become a development tool for disadvantaged peripheral regions. Such developments require multi-faceted professional inventory and assessment of the elements of geodiversity. Similar requirements are also necessary with respect to geoconservation and the evaluation of vulnerability risks. The basic unit of the geodiversity register is the geosite. This may include outcrops or man-made excavations, (abandoned) mines or other anthropogenic objects; the main point is that their identification is connected to the developing geological and geomorphological processes (e.g. geosites with volcanic or karstic features).

Based on the above, this study provides an overview of the development in geosite assessment and evaluation work, with special emphasis on the recently published details concerning two quantitative methods. This methodological basis was used to assess the well-known - albeit less representative - geosites of the domestic geological heritage. The scientific-educational, scenic-aesthetic potential and protection-degradation risk scores were determined discretely for 60 geosites. A particular focus was centred on the different nature conservation conditions (national park, landscape protection area, protected natural area, ex lege etc.), as well as on the development of the geo-touristic infrastructure (visitor centres, exhibition sites, nature trails). All this took place within the framework of the evaluation of additional interpretative and geo-touristic potential scores. The authors were actively involved in the establishment of a special Hungarian Geosite Day, with the specific aim of promoting the public dissemination of the geosciences.

Keywords: geoheritage, geosite, inventory, assessment, geopark

Összefoglalás

A természeti környezet abiotikus tényezőit összefoglaló geodiverzitás jelentőségének felismerése az elmúlt 30 évben kapott egyre szélesebb körû nyilvánosságot. Az erre épülố geoturizmus a bemutatóhelyek számának növekedésével, minőségi fejlesztésével látványos növekedésen ment keresztül, ahogyan a két hazai UNESCO Globális Geopark (NovohradNógrád, Bakony-Balaton) látogatottsága is bizonyítja. Az ilyen jellegú fejlesztések a geodiverzitás elemeinek több szempontú szakmai felmérését, minősítő értékelését igénylik. Hasonló elvárás merül fel a földtudományi természetvédelem részérôl is a veszélyeztetettségi kockázatok meghatározásában. A geodiverzitás minősítésére koncentráló kataszteri munka alapegységét a geotópok képezik, amelyek lehetnek természetes vagy mesterséges feltárások, (felhagyott) bányák, egyéb antropogén hatásra létrejött objektumok, de egyedi azonosításukat mindenképpen a létrehozó geológiai, geomorfológia folyamat(ok) teszi(k) lehetővé (vulkáni, karszt stb. geotópok).

Ezek alapján tanulmányunk áttekintést nyújt a geotóp minősítés és értékelés fejlődéséről, külön kiemelve a közelmúltban publikált két kvantitatív módszert, amelyeket a hazai földtudományi örökség jól ismert és kevésbé reprezentatív objektumainak értékeléséhez használtunk fel. A mintegy 60 geotóp esetében külön-külön meghatároztuk a tudományosoktatási, tájképi-esztétikai, turisztikai potenciál és védelem-veszélyeztetettségi kockázatok értékeit. Ehhez társul bemutathatóság-geoturisztikai potenciál minősítése, külön hangsúlyt fektetve a geotópok eltérő jogi védelméből (pl. nemzeti park, tájvédelmi körzet, természetvédelmi terület, ex lege) és a geoturisztikai infrastruktúra eltérő fejlettségéből (látogatóközpontok, bemutatóhelyek, tanösvények) jelentkező különbségekre. A szerzók aktívan közremúködtek a Magyar Geotóp nap rendezvénysorozat életre hívásában, ennek megfelelően a tanulmány a földtudományi ismeretterjesztés lehetôségeit is számba veszi. 


\section{Bevezetés}

A földtani értékek jelentőségének felismerése hazai és nemzetközi téren is több mint 200 éves múltra tekint vissza (Gellai \& BARoss 1995, TARdY et al. 2006, Bedó et al. 2006). Habár az elsố védett földtani képződménynek az edinburghi Arthur's Seat egyik felhagyott kőbányájában található, James HuTTON kérésére meghagyott hematitos telérmaradványt, az ún. Hutton's Rock-ot tekintik (MCADAM \& ClARKSON 1986). Az ősmaradványok, ásványok tudományos leírása és múzeumokban történő (ex-situ) elhelyezése után a tényleges lelőhely szintú (in-situ) védelemre még sokáig várni kellett. Az elsô nemzeti parkok létrehozása mellett (1872. Yellowstone, USA, 1883. Banff, Kanada, 1903. Abisko, Svédország) azonban sok kisebb ősmaradvány-lelőhely a gyưjtés áldozatául esett (pl. Cromarty, Old Red Sandstone, Skócia). Magyarországon az elsô védelemre irányuló intézkedés az ipolytarnóci kövült fa darabjainak múzeumokba szállítása volt. A törzs fölé emelt védôpince létrehozása után (1866) tényleges jogi védelem alá azonban csak 1944-ben került (TARDY et al. 2006).

A második világháborút követôen a mobilitás növekedésével a turisztikai ágazat jelentős fejlődésnek indult. A tömegigények kielégítése mellett a fenntartható turizmus (ökoturizmus) 1980-as, míg a geológiai, táji értékekre fókuszáló geoturizmus a 90-es években jelent meg. A földtudományi értékek iránti érdeklődést és a bemutatásukra irányuló társadalmi igényt a nemzetközi és hazai geoparkok, bemutatóhelyek egyre növekvő száma mutatja. Ez a tudomány számára is új kihívást jelent, amely az értékek, helyszínek (geotópok) kataszteri felmérése mellett a potenciális veszélyek (védelem) és a geoturisztikai hasznosítás gyakran egymással szemben álló lehetôségeinek minősítését kívánja meg.

A geodiverzitás fogalma a 90-es évek elsô felében Ausztráliában jelent meg (SHARPLES 1993), majd kapott egyre tágabb jelentéstartalmat (GRAY 2004, 2008). A geodiverzitás objektumként is azonosítható elemeit a geotópok (angol irodalomban geosite) jelentik, amelyek többszintû minősítő értékelése (tudományos, esztétikai, kulturális, turisztikai) azonban már Európához kötődik. A geológusok és geomorfológusok által képviselt kutatómúhelyek (Portugália, Svájc, Görögország, Szlovénia) a vizsgált faktorok egyre szélesebb körével minősítették a kataszterezett objektumokat, amellyel az értékelés módszertanilag is egyre megalapozottabbá vált. Ezzel a geoturisztikai ágazat által támasztott igényeket is hatékonyabban tudták kielégíteni (védettség, bemutathatóság) és a további fejlesztési prioritások meghatározásában is egyre fontosabb szerephez jutottak (FEUILLET \& SuRP 2011, REYNARD et al. 2016, PoIRAUd et al. 2016).

Hazánkban az első védetté nyilvánítás óta (1939, Nagyerdő) több száz természeti érték került oltalom alá, amelyek között nagy számban találunk földtani-felszínalaktani szempontból is fontos területeket, ahogyan ezt az elsô létrehozott tájvédelmi körzet is bizonyítja (1952, Tihanyi Tájvédelmi Körzet). A természet védelméról szóló 1996. évi LIII. törvény értelmében hazánkban az élettelen természet egyes különleges képződményei ex lege védelem alatt áll- nak (barlang, forrás, víznyelő), amelyekről részben országos adatbázis is rendelkezésre áll (Országos Barlangnyilvántartás, forráskataszter, víznyelőkataszter). A földtani alapszelvények katasztere mellett, az egyéb földtudományi, felszínalaktani és talajtani képződmények esetében országos kataszter még nem készült.

Tanulmányunk célja, hogy a geotóp minôsítés és értékelés módszertani fejlődéséről vázlatos áttekintést nyújtson, emellett szeretnénk megtalálni az eddigi hazai szakmai munka közös metszéspontjait. Az összehasonlító értékeléshez a hazai földtani örökség néhány kiemelt és kevésbé reprezentatív objektumát használtuk fel, amellyel a módszerek és objektumok (geotópok) közötti különbségek is értékelhetővé válnak.

\section{A geotópok felmérésének, értékelésének történeti áttekintése}

A földtani örökség felmérése, védelme és bemutatása az elmúlt 30 évben jelentôs átalakuláson ment keresztül (REYNARD et al. 2015). Számos ország hozott létre önálló kataszteri szabványt, amelyek közül az első az Egyesült Királyság területi nyilvántartása volt (1950-es évektől). Az ebben szereplő több mint 3000 objektum mindegyike jogi védelem alatt áll (Sites of Special Scientific Interest, WiMBLEDON et al. 1995). Ezt az 1970-es évektől több ország követte (pl. Spanyolország - CARCAVILLA et al. 2007; Svájc REYNARD et al. 2007). Az elkészült nemzeti katasztereket az International Union of Geological Sciences (IUGS) földtani örökségvédelmi alcsoportja (2010, Geoheritage Task Group) térképi adatbázisban tette elérhetôvé (http://geoheritageiugs.mnhn.fr/). A környező országok adatbázisai mellett (Szlovákia, Cseh- és Lengyelország) ebben hazánk egyelőre nem szerepel.

A földtudományi örökség minősítésével, kataszterezésével és kezelésével, ajánlások megfogalmazásával több nemzetközi szervezet foglalkozik. Az 1972-ben alakult World Heritage Convention mintegy 180 földtani objektumot vett föl listájára, mint természeti értéket, de több olyan kulturális világörökségi helyszín van, amely jelentős földtani értéket is képvisel (pl. Selmecbánya-Szlovákia, HERČKO et al. 2014, Tokaj-hegyaljai borvidék, SzEPESI et al. 2015, 2017). A Global Geosites Inventory programot a már említett IUGS indította (WIMBLEDON et al. 1999), azonban ez 2003-ban minden folytatás nélkül megszakadt. A European Association for the Conservation of the Geological Heritage (Progeo 2011) adatfelvételi lapját több ország is használja a nemzeti regiszterek összeállításában (pl. BRUM DA SILVEIRA et al. 2015). Az International Association of Geomorphologist (IAG) Geomorphosite munkacsoportja fôként a geomorfológiai szempontból fontos helyszínekkel foglalkozik (REYNARD \& CORATZA 2013)

Ezek a kezdeményezések egyre több módszertani kérdést vetettek föl, amelyeket geotópok kataszterezésével és minősítésével foglalkozó kutatások igyekeztek megválaszolni. Az Európában kibontakozó irányzat legfontosabb tu- 
dományos múhelyei (I. táblázat, Olaszország, Spanyolország, Portugália, Görögország, Svájc, Szlovákia) számos értékminősítő rendszert dolgoztak ki, amelyek a geotópok tudományos értékének meghatározása mellett egyre több hozzáadott érték kategóriát mért fel (esztétikai, kulturális, turisztikai). A kvalitatív értékelés mellett fokozatosan előtérbe került a geotópok számszerú minôsítése és különböző szempontú rangsorolása.

I. táblázat. A földtudományi értékek felmérésének és minősítésének legfontosabb hazai és nemzetközi kutatóhelyei

Table I. Domestic and international research groups of geosite inventory and assessment work

\begin{tabular}{|l|l|l|}
\hline & \multicolumn{1}{|c|}{ Kutatóhely } & \multicolumn{1}{c|}{ Irodalom } \\
\hline 1. & Lausanne, Svájc & $\begin{array}{l}\text { PRALONG \& REYNARD 2005, REYNARD et } \\
\text { al. 2007 }\end{array}$ \\
\hline 2. & Minho, Portugália & PEREIRA et al. 2007, BRILHA 2016 \\
\hline 3. & $\begin{array}{l}\text { Cantabria, Valladolid } \\
\text { Spanyolország }\end{array}$ & $\begin{array}{l}\text { BRUSCHI \& CENDRERo 2005, BRUSCHI et } \\
\text { al. 2011, SERRANO \& TRUEBA 2005 }\end{array}$ \\
\hline 4. & Modena, Olaszország & PANIZZA 2001, CORATZA \& GIUSTI 2005 \\
\hline 5. & Mitylene, Kréta Görögország & ZOUROS 2005, FASSOULAS et al. 2012 \\
\hline 6. & Párizs, Franciaország & FEUILLET \& SoURP 2010 \\
\hline 7. & Novi Sad, Szerbia & VUJICIC et al., 2011, VISNIC et al. 2011 \\
\hline 8. & Kassa, Szlovákia & RYBÁR 2010, STRBA 2015 \\
\hline 9. & Debreceni és Corvinus Egyetem & KISS 1999, 2001, 2005a, b, 2008 \\
\hline
\end{tabular}

Az első kvantitatív módszerek a tudományos értékre fókuszáltak (GRANDGIRARD 1999, REYNOLDS 2001) és további, a hasznosítás szempontjából fontos indikátorokat (funkcionális értékek) nem vettek figyelembe. Környezeti hatásvizsgálatokhoz kapcsolódóan PANIzZA (2001) által javasolt módszer definiálta a geomorfotóp fogalmat, erre épülve a geomorfológiai értékek feltárása többek között svájci kutatók tevékenységével vált önálló kutatási irányzattá (REYNARD et al. 2009). Ebben REYNARD (REYNARD et al. 2007, IIa táblázat) viszonylag egyszerú módszere a tudományos indikátorok körét hozzáadott értékekkel (ökológiai, esztétikai, kulturális, gazdasági) bővítette.

Az értékelés céljainak pontosabb meghatározása újabb indikátorok bevezetésével járt. A hozzáadott értékeken belül megjelent az oktatási-nevelési jelentőség (SERRANO \& GONZALEZ TRUEBA 2005). A minősített fő értékek köre a védelem és lehetséges veszélyek szempontrendszerével bővült (BRUSCHI \& CENDRERO 2005), valamint megjelentek a funkcionális értékek (Serrano \& Gonzalez Trueba 2005, Bruschi \& CENDRERo 2005, IIb táblázat). A PereIRA et al. (2007) által publikált módszer két főcsoporton (geomorfológia és geotópkezelés) belül 4 értékkategóriát definiált (tudományos, hozzáadott, használati, védelmi), amelyek kapcsolódó indikátorok segítségével egyre részletesebben írták le az objektumot. A geotópok környezetét jellemző geodiverzitás fogalmának önálló kategóriaként történô bevezetése ZouROS (2007) nevéhez fúződik, amely késôbb a tudományos értékek körét bővítette (FASSOULAS et al. 2012, BRILHA 2016).

A geoturizmus cél- és eszközrendszere további minôsített szempontokat igényelt. Ezekkel egyrészt bóvült a funkcionális értékek köre (pl. bemutathatóság, közúthálózat minősége), valamint önálló csoportdefinícióként megjelent a turisztikai érték. Elsőként PRALONG (2005) a Chamonix környéki glaciális formakincset tanulmányozva minősítette a tudományos és hozzáadott értékek turisztikai hasznosí- tását. FEUILLET \& SOURP (2011) korlátozott számú indikátor alapján a franciaországi Pireneusok Nemzeti Park számára határozta meg a vizsgálatba bevont geotópok turisztikai fejlesztési prioritásait (IIa és b táblázat). Integrálva az addigi eredményeket, új indikátorok bevezetésével a szlovén és szerb kutatók új geotóp minôsítő rendszert hoztak létre (geosite assessment model, GAM: ERHARTIC 2010, VuJIČIĆ et al. 2011, VIŠNIĆ et al 2011). A két fő kategórián belül (a fő és járulékos) a legtöbb vizsgált mutatót tartalmazó rendszer súlyozás nélkül is alkalmas a geotópok tudományos, védelmi, funkcionális és turisztikai jellemzőnek leírására és összegző értékelésre. A módszert több egyéb területen is alkalmazták (vulkáni geotópok: MoUFTI et al. 2013, SzEPESI et al. 2017). A Kassai Egyetemen folyó kutatások 2010-ben hívták életre az Acta Geotouristica folyóiratot. Értékelési rendszerük a geoturizmus számára fontos természeti és antropogén geotópokat különböző jellemzők alapján minősítette (RYBAR 2010, ŠTrBA 2015).

A szubjektivitás csökkentése az értékelési folyamat meghatározó eleme. Ez egyrészt az indikátorok súlyozásával, másrészt a súlyozási értékek meghatározása során külső szakértők bevonásával érhető el (BRUSCHI et al. 2011). Ezt az elvet alkalmazta a legutóbb publikált módszer (BRILHA 2016), amely részben azonos indikátorok eltérô súlyozásával határozta meg a geotópok tudományos, oktatási-nevelési, turisztikai és veszélyeztetettségi potenciálját.

A hazai kvantitatív értékminősítő munka (KozÁK et al. 1998, KISs 1999) mintegy 10 évvel előzte meg a nemzetközi szakirodalomban publikált módszereket, amelyek alkalmazhatóságáról a Magyarhoni Földtani Társulat szakmai vitafórumot is rendezett 2000-ben. A Debreceni Egyetem Ásvány- és Földtani Tanszékén kidolgozott rendszer (KozÁK et al. 1998, SzEPESI \& ÉSIK 2000) a geotóp mérete, a benne megjelenő értékek diverzitása, alapszelvény jellege, valamint oktatási-kutatási jelentősége alapján határozott meg szorzószámokat. Ehhez járult hozzá az emberi beavatkozás mértékének minősítése, ahol a negatív hatások csökkentették az objektum értékszámát. A földtani (eszmei) érték számítása mellett a nyersanyag és rekultivációs költségek becslésével tettek kísérletet az emberi hatások összegszerú meghatározására.

KISS (1999) a talajok és morfológiai formák természetvédelmi jelentőségének meghatározására dolgozott ki módszert. Erre épült a földtudományi képződmények természetvédelmi értékelése (2003-2007, KISS \& HoRvÁTH 2003; KIss 2005a, b, 2008). A kataszteri lap összeállítása során az addigi szakmai előzményeket használták fel (kunhalom-felmérés, egyedi tájérték adatlap, a védett természeti területek és értékek nyilvántartásáról szóló 13/1997. (V.28.) KTM rendeletet). A pontszámszerú minősítés indikátorai összhangban állnak a nemzetközi módszertannal (pl. egyedülállóság, ritkaság, természetesség, típusosság, kutatási, oktatási-nevelési, turisztikai-rekreációs jelentőség). A területileg korlátozott felmérésből sajnos nem lett országos program, de válogatott geotópok anyagait reprezentatív kiadványban jelentették meg (KISS \& BENCKHARD 2007).

A hazai értékvédelmi munkában külön kategóriát képez- 
IIa táblázat. Fő értékkategóriák és indikátoraik használata a földtudományi értékminősítés nemzetközi gyakorlatában

Table 2a. Use of of main geoheritage values and their indicators in the international geosite assessment methodology

\begin{tabular}{|c|c|c|c|c|c|c|c|c|c|}
\hline Értékkategóriák és jellemzők & 1 & 2 & 3 & 4 & 5 & 6 & 7 & 8 & 9 \\
\hline Tudományos érték & $\mathrm{X}$ & $\mathrm{X}$ & $\mathrm{X}$ & $\mathrm{X}$ & $\mathrm{X}$ & $\mathrm{X}$ & $\mathrm{X}$ & $\mathrm{X}$ & $\mathrm{X}$ \\
\hline Tudományos megismerés szintje (scientific knowledge) & & $\mathrm{X}$ & $\mathrm{X}$ & $\mathrm{X}$ & & $\mathrm{X}$ & $\mathrm{X}$ & $\mathrm{X}$ & \\
\hline Ritkaság/Gyakoriság (rareness, rarity/abundance) & $\mathrm{X}$ & $\mathrm{X}$ & $\mathrm{X}$ & $\mathrm{X}$ & $\mathrm{X}$ & $\mathrm{X}$ & $\mathrm{X}$ & $\mathrm{X}$ & $\mathrm{X}$ \\
\hline Sértetlenség (integrity) & $\mathrm{X}$ & $\mathrm{X}$ & $\mathrm{X}$ & $\mathrm{X}$ & $\mathrm{X}$ & $\mathrm{X}$ & $\mathrm{X}$ & & \\
\hline Reprezentativitás (representativeness) & $\mathrm{X}$ & $\mathrm{X}$ & $\mathrm{X}$ & $\mathrm{X}$ & $\mathrm{X}$ & $\mathrm{X}$ & $\mathrm{X}$ & & $\mathrm{X}$ \\
\hline Diverzitás (diversity) & & $\mathrm{X}$ & $\mathrm{X}$ & $\mathrm{X}$ & $\mathrm{X}$ & & & & $\mathrm{X}$ \\
\hline Típusosság (exemplarity) & & & & & $\mathrm{X}$ & & & & $X$ \\
\hline Egyéb földtani örökség (association with other heritage value) & & $\mathrm{X}$ & $\mathrm{X}$ & $\mathrm{X}$ & & & & $\mathrm{X}$ & \\
\hline Paleogeográfiai érték (palaeogeographical value) geomorfotóp jellemző & $\mathrm{X}$ & & $\mathrm{X}$ & & $\mathrm{X}$ & & & & \\
\hline Típuselőfordulás (key locality), Korlátozások (use limitation) & & $\mathrm{X}$ & $\mathrm{X}$ & & & & & $\mathrm{X}$ & $\mathrm{X}$ \\
\hline \multicolumn{10}{|l|}{ Járulékos érték (added value) } \\
\hline Esztétikai érték 1. (láthatóság, nézőpontok) & $\mathrm{X}$ & $\mathrm{X}$ & $\mathrm{X}$ & $\mathrm{X}$ & $\mathrm{X}$ & $\mathrm{X}$ & $\mathrm{X}$ & $\mathrm{X}$ & $\bar{X}$ \\
\hline $\begin{array}{l}\text { Esztétikai érték 2. (felszín, környezö természeti táj állapota, geotóp } \\
\text { illeszkedése a környezetbe) }\end{array}$ & & & & & & & $X$ & $X$ & $X$ \\
\hline Kulturális értékek (vallási, történelmi, néprajzi, múvészeti) & $\mathrm{X}$ & $\mathrm{X}$ & $\mathrm{X}$ & $\mathrm{X}$ & $\mathrm{X}$ & $\mathrm{X}$ & $\mathrm{X}$ & $\mathrm{X}$ & \\
\hline Ökológiai értékek (ecological values) & $\mathrm{X}$ & $\mathrm{X}$ & & & $\mathrm{X}$ & & $\mathrm{X}$ & & $\mathrm{X}$ \\
\hline Oktatási érték (educational value) & & $\mathrm{X}$ & $\mathrm{X}$ & & & & & & $\mathrm{X}$ \\
\hline Turisztikai bemutathatóság (tourist attraction) & & & $\mathrm{X}$ & & & & & $\mathrm{X}$ & $\mathrm{X}$ \\
\hline \multicolumn{10}{|l|}{ Védettség és potenciális veszélyek } \\
\hline Sebezhetőség (vulnerability, fragility) & & $\mathrm{X}$ & $\mathrm{X}$ & & $\mathrm{X}$ & $\mathrm{X}$ & $\mathrm{X}$ & & \\
\hline Védelem (protection) & $\mathrm{X}$ & $\mathrm{X}$ & $\mathrm{X}$ & $\mathrm{X}$ & $\mathrm{X}$ & & $\mathrm{X}$ & & $\mathrm{X}$ \\
\hline Ökológiai értékek (ecological values) & $\mathrm{X}$ & $\mathrm{X}$ & & & $\mathrm{X}$ & & $\mathrm{X}$ & & \\
\hline Természetesség (naturalness) & & & $\mathrm{X}$ & & & & & & $X$ \\
\hline Elfogadható változás mértéke & & & & & $\mathrm{X}$ & & & & \\
\hline Megfelelö látogatószám (use limitation) & & $\mathrm{X}$ & $\mathrm{X}$ & & & & $\mathrm{X}$ & & $\mathrm{X}$ \\
\hline Degradációs kockázat (degradation risk) több indikátor & & $\mathrm{X}$ & $\mathrm{X}$ & & & & & & \\
\hline
\end{tabular}

2b táblázat. Funkcionális és geoturisztikai potenciál értékkategóriák és indikátoraik használata a földtudományi értékminősítés nemzetközi gyakorlatában

Table2b. Use of functional and geotouristic values and their indicators in international geosite assessment methodology

\begin{tabular}{|c|c|c|c|c|c|c|c|c|c|}
\hline Értékkategóriák és jellemzők & 1 & 2 & 3 & 4 & 5 & 6 & 7 & 8 & 9 \\
\hline \multicolumn{10}{|l|}{ Funkcionális értékek } \\
\hline Megközelíthetőség (accessibility) & & $\mathrm{X}$ & $\mathrm{X}$ & $\mathrm{X}$ & $\mathrm{X}$ & $\mathrm{X}$ & $\mathrm{X}$ & $\mathrm{X}$ & $\mathrm{X}$ \\
\hline Méret (size, extent) & & & $\mathrm{X}$ & $\mathrm{X}$ & & & $\mathrm{X}$ & & \\
\hline A geotóp, geomorfotóp jelenlegi bemutathatósága & & $\mathrm{X}$ & & & $\mathrm{X}$ & & $\mathrm{X}$ & $\mathrm{X}$ & \\
\hline Gazdasági tevékenység a geotóp közelében & $\mathrm{X}$ & $\mathrm{X}$ & $\mathrm{X}$ & $\mathrm{X}$ & & & & & \\
\hline $\begin{array}{l}\text { Potenciális keresleti központok távolsága és népsürüség (density of } \\
\text { population) }\end{array}$ & & $\mathrm{X}$ & & & & & $\mathrm{X}$ & & \\
\hline Közúthálózat minősége és távolsága (logistics) & & $\mathrm{X}$ & & & & & $\mathrm{X}$ & & $\mathrm{X}$ \\
\hline Biztonság & & $\mathrm{X}$ & & & & & & $\mathrm{X}$ & $\mathrm{X}$ \\
\hline Turisztikai érték (touristic values) & & $\mathrm{X}$ & & & & & $\mathrm{X}$ & & \\
\hline Promóció & & & & & & & $\mathrm{X}$ & $\mathrm{X}$ & \\
\hline Vezetett túrák éves száma & & & & & & & $\mathrm{X}$ & & \\
\hline Látogató központ távolsága & & & & & & & $\mathrm{X}$ & & \\
\hline Interpretáció típusa, minősége & & $\mathrm{X}$ & & & & & $\mathrm{X}$ & $\mathrm{X}$ & \\
\hline Éves látogatószám & & & & & $\mathrm{X}$ & & $\mathrm{X}$ & & \\
\hline Turisztikai infrastruktúra minősége & & & & & & & $\mathrm{X}$ & $\mathrm{X}$ & \\
\hline Túravezetés & & & & & & & $\mathrm{X}$ & & \\
\hline Szállás és éttermi szolgáltatás & & & & & & & $\mathrm{X}$ & & \\
\hline Gazdasági fejlettség & & $\mathrm{X}$ & & & & & & & \\
\hline Rekreációs központok távolsága & & $\mathrm{X}$ & & & & & & & \\
\hline Kulturális utak és bányászati örökség & & & & & & & & $\mathrm{X}$ & \\
\hline
\end{tabular}

nek a tájkaraktert meghatározó egyedi tájértékek, amelyek közé a geodiverzitást növelő földtudományi értékek is tartoznak. Ezeket a kapcsolódó szabvány (MSZ20381: 2009) alapján önálló kataszteri program keretében mérték fel (SzABÓ \& SÜTŐ 2005, KISS \& BABUs 2011, KIss et al. 2011). A felmé- réseket elősegítette a 2009-2010-ben Tájérték Kataszter (TÉKA) program, amellyel integrált adatbázis jött létre. Az eredményeinek közzétételét interaktív térképi keresővel ellátott közösségi modul biztosítja (www.tajertektar.hu).

A Magyar Bányászati és Földtani Szolgálat és a jogelőd 
intézmények (Magyar Állami Földtani Intézet, Magyar Állami Földtani és Geofizikai Intézet) kiemelt feladata volt és marad a földtani értékek felmérése és minél szélesebb körû́ megismertetése és népszerúsítése. Az 1970-es évektől az Országos Alapszelvény Program keretében (HAAs \& JÁMBOR 1983, GELLAI \& BAROSS 1995) kezdôdött a sztratigráfiai szempontból kiemelkedő fontosságú felszíni feltárások és mélyfúrások védetté nyilvánítása, amelynek keretében 1985-91 között 151 felszíni és 238 fúrási alapszelvényt publikáltak, területileg és korviszonyaikat tekintve is egyenlőtlen eloszlásban. Ma a Magyar Rétegtani Bizottság mintegy 500 felszíni alapszelvényt tart nyilván.

A rendelkezésre álló adatbázis digitális tartalomfejlesztése révén az érdeklődô szakmai közönség számára is elérhetővé tették. Ennek köszönhetően elmúlt években több regionális (ALBERT \& CSILLAG 2011, GYALOG et al. 2017) és országos kiadványt (BUDAI \& GYALOG 2009) jelentettek meg, amelyek a Magyar Bányászati és Földtani Szolgálat honlapján digitális térképek formájában is hozzáférhetőek.

Az elmúlt években a Földmúvelésügy Minisztérium több tájegységben megkezdte a további objektum alapú védetté nyilvánítás elókészítését. Ennek köszönhetôen a földtani alapszelvények és földtani képződmények védetté nyilvánításáról és természetvédelmi kezelési tervéről szóló 55/2015. (IX. 18.) FM rendelet meghatározta az objektum alapú védelem jogszabályi kereteit. 2015-ben a rendelet 43 természeti emléket és országos jelentôségú védett természeti terület részterületét nevesítette (pl. Bér andezitoszlopok, Kaszonyi-hegy), ahol a kezelési dokumentációk tartalmazzák a védelem, látogatás, oktatás, bemutatás, kutatással, területhasználattal kapcsolatos előírásokat. De a védetté nyilvánítás és a lista bővítése folyamatosan zajlik (pl. Vizsoly kőfejtó).

\section{Az összehasonlító értékelés módszertana}

\section{Alapfogalmak}

A módszertan rendszerének áttekintéséhez szükséges az értékminősítés legfontosabb alapfogalmainak ismerete, amelyet a III. táblázat tartalmaz. A geodiverzitás és a kataszteri munka alapegysége a geotóp, amelyet legfontosabb tulajdonságaként tudományos értéke jellemez. A geotóp fölött hierarchiában a nagyobb felszínalaktani egységek a geomorfotópok állnak, amely akár több önálló geotópot

III. táblázat. A földtudományi értékek védelemének és bemutatásának legfontosabb alapfogalmai

Table III. The basic concepts of the geoconservation and its interpretation

\begin{tabular}{|c|c|c|}
\hline Fogalom & Értelmezés & Irodalom \\
\hline $\begin{array}{l}\text { Geotóp } \\
\text { (geosite) }\end{array}$ & $\begin{array}{l}\text { A geotópok az élettelen természeti képződményeket reprezentáló objektumok, amelyek a földtörténet } \\
\text { egy-egy időszakában lezajlott folyamatok megértésében különös jelentőséggel bírnak. Térben jól } \\
\text { lehatárolható, földtani vagy geomorfológiai egységek, amelyek jelentős tudományos (pl. földtani } \\
\text { alapszelvények), kulturális/történelmi esztétikai és társadalmi-gazdasági értékkel rendelkeznek. A } \\
\text { geotópok jellegük alapján tovább osztályozhatók felszínformák, sziklafalak, barlangok, közetek vagy } \\
\text { talajok természetes és mesterséges feltárásai, tájelemek, források, ásvány-, vagy kövület- } \\
\text { előfordulások csoportjaira. }\end{array}$ & $\begin{array}{l}\text { BARETTINO et al. } 1999, \\
\text { GRANDGIRARD } 1999, \\
\text { WIMBLEDON et al. 1995, } \\
\text { REYNARD 2004, BRILHA } \\
2011\end{array}$ \\
\hline $\begin{array}{l}\text { Egyedi tájérték } \\
\text { (geodiversity site) }\end{array}$ & $\begin{array}{l}\text { A természet védelméröl szóló 1996. évi LIII. törvény (Tvt.) 6. § (3) (4) és (5) bekezdése értel- } \\
\text { mében egyedi tájértéknek minősül az adott tájra jellemző olyan természeti érték, képződmény és az } \\
\text { emberi tevékenységgel létrehozott tájalkotó elem, amelynek természeti, történelmi, kultúrtörténeti, } \\
\text { tudományos vagy esztétikai szempontból a társadalom számára jelentósége van. A földtudományi } \\
\text { vonatkozási egyedi tájértékek jelentéstartalma megegyezik a BRILHA (2016) által definiált } \\
\text { geodiversity site fogalmával. }\end{array}$ & $\begin{array}{l}\text { MSZ 20381:1999 } \\
\text { szabvány 1996. évi LIII. } \\
\text { törvény, } \\
\text { KISS et al. } 2011 \\
\text { BRILHA } 2016\end{array}$ \\
\hline $\begin{array}{l}\text { Geomorfotóp } \\
\text { (geomorphosite) }\end{array}$ & $\begin{array}{l}\text { A nemzetközi szakirodalomban a geomorfológiai szempontból fontos felszínformák megkülön- } \\
\text { böztetésére szolgáló fogalom, amelyeket a társadalom többféle hozzáadott értékkel ruház föl. Ezek } \\
\text { több különálló geotópot és egyedi tájértéket tartalmazhatnak. A felszínformáló folyamatok } \\
\text { aktivitása alapján a jelenleg is fejlödő formák az aktív, míg az inaktív vagy fosszilis térszínek } \\
\text { (paleokarszt) a passziv geomorfotóp besorolást kapták. }\end{array}$ & $\begin{array}{l}\text { PANIZZA 2001, PANIZZA } \\
\& \text { PIACENTE } 2005 \\
\text { PEREIRA \& PEREIRA } \\
2010, \text { PELFINI \& } \\
\text { BOLLATI } 2014\end{array}$ \\
\hline $\begin{array}{l}\text { Geodiverzitás } \\
\text { (geodiversity) }\end{array}$ & $\begin{array}{l}\text { Az elsöként Ausztráliában definiált fogalom a 1990-es évek közepétől kapott egyre szélesebb jelentéstar- } \\
\text { talmat. A földtani, geomorfológiai és talajobjektumok, rendszerek és folyamatok természetes változa- } \\
\text { tosságát jelenti. Magában foglalja a földtörténeti múlt ökoszisztémáinak és környezeti rendszereit, éppúgy, } \\
\text { mint a jelenleg is aktív légköri, hidrológiai és biológiai folyamatokat, amelyek aktívak részt vesznek a } \\
\text { kőzetek, felszínformák és a talajok kialakulásában, fejlödésében. }\end{array}$ & $\begin{array}{l}\text { SHARPLES } 1993, \text { GRAY } \\
2004,2008 \text { ZWOLINSKI } \\
2004\end{array}$ \\
\hline $\begin{array}{l}\text { Földtani örökség } \\
\text { (geoheritage) }\end{array}$ & $\begin{array}{l}\text { A természetes geodiverzitás azon eleme, amely a geotóp fogalmánál ismertetett szempontok alapján } \\
\text { (tudományos, esztétikai, kulturális-történelmi, társadalmi-gazdasági) alapján a társadalom számára } \\
\text { értéket hordoz. A földtani örökség legfontosabb, védett objektumai kiemelt érdeklődésre tarthatnak } \\
\text { számot. Bemutatásuk fontos a földtörténeti múlt, az élet fejlödésének, az ásványi nyersanyagok és } \\
\text { energiahordozók bemutatásában, valamint az éghajlati és környezeti változások, talajképzódési } \\
\text { folyamatok, természeti katasztrófák megértésében. }\end{array}$ & $\begin{array}{l}\text { O' HALLORAN et al. } \\
\text { 1994, GSA } 2011, \\
\text { Progeo } 2011, \text { BROCX \& } \\
\text { SEMENIUK } 2007\end{array}$ \\
\hline In situ érték & előfordulási helyszíneken (geotóp) tanulmányozható, bemutatható földtudományi értékek. & BRILHA 2016 \\
\hline Ex situ & $\begin{array}{l}\text { A tudományos értékét megtartó, de nem eredeti előfordulási helyén (múzeum, bemutatóhely) } \\
\text { tanulmányozható földtudományi érték (kövület, ásvány, kőzet). }\end{array}$ & $\begin{array}{l}\text { KozÁK et al. 1998, } \\
\text { BRILHA } 2016\end{array}$ \\
\hline
\end{tabular}


III.táblázat. Folytatás

Table III. Continuation

\begin{tabular}{|c|c|c|}
\hline Fogalom & Értelmezés & Irodalom \\
\hline $\begin{array}{l}\text { Földtani } \\
\text { értékmegőrzés } \\
\text { (geoconservation) }\end{array}$ & $\begin{array}{l}\text { Az értékmegörzés a földtani örökség jogi védelme mellett annak azoknak a tevékenységeknek az } \\
\text { összességét jelenti, amely az érték minőségének megörzése mellett lehetővé teszik azok fenntartható } \\
\text { hasznositását. Hazánkban az } 1996 \text { évi LIII. törvény alapján a földtani természeti értékek védelme a } \\
\text { tájvédelmet, továbbá az élettelen és meg nem újítható természeti erőforrások, és az élővilág } \\
\text { létfeltételeinek megóvását szolgálja. A földtani természeti értékek általános védelme kiterjed a } \\
\text { földtani, felszínalaktani képződményekre, ásványokra, ásványtársulásokra, ősmaradványokra. }\end{array}$ & $\begin{array}{l}\text { BRILHA 2002, } \\
\text { SHARPLES 2002, } \\
\text { BROCX \& SEMENIUK } \\
\text { 2007, GSA 2011, } \\
\text { Progeo 2011, } \\
\text { BUREK \& PROSSER } 2008\end{array}$ \\
\hline $\begin{array}{l}\text { Értékkataszter } \\
\text { (geosite inventory) }\end{array}$ & $\begin{array}{l}\text { A geotópok egységes szempontú felmérésen alapuló adatbázisa, a földtani értékvédelmi stratégia } \\
\text { kidolgozásának alapvető eleme. Készülhet kisebb (tájegységi) és nagyobb (országos) léptékben. A } \\
\text { célok és módszerek egyértelmü meghatározása mellett a földtudományi szakterületek szoros együtt- } \\
\text { müködését igényli, amellyel mérsékelhető szubjektivitás és elérhetö a különböző kategóriák } \\
\text { (geológia, geomorfológia, talajtan stb.) egységes kataszterezése. }\end{array}$ & $\begin{array}{l}\text { WIMBLEDON et al. } 1995 \text {, } \\
\text { 1999, BRILHA } 2016, \\
\text { REYNARD et al } 2016, \\
\text { PoIRAUD et al. } 2016\end{array}$ \\
\hline $\begin{array}{l}\text { Értékminősités } \\
\text { (geosite } \\
\text { assessment) }\end{array}$ & $\begin{array}{l}\text { Az értékkataszter elemeinek minőségi és mennyiségi alapú minősítése. A kvalitatív módszer az } \\
\text { elsődleges szelekció részeként megelőzheti a számszerű értékelést. A minősitő szempontok közül a } \\
\text { legfontosabbak a tudományos, természetvédelmi, oktatási, turisztikai változók. Az elmúlt } 10 \text { év } \\
\text { módszertani eredményei mellett nemzetközi szinten sincs egységesen elfogadott módszer. A végső } \\
\text { értékelés történhet azonos pontértékü számítási módszerekkel és súlyozott paraméterek alapján. }\end{array}$ & $\begin{array}{l}\text { BRUSCHI et al. 2011, } \\
\text { ERHARTIC } 2010, \\
\text { FEUILLET \& SOURP } \\
\text { 2011, FASSOULAS et al. } \\
2012 \text {, } \\
\text { BRILHA } 2016 \\
\end{array}$ \\
\hline $\begin{array}{l}\text { Geoturizmus } \\
\text { (geotourism) }\end{array}$ & $\begin{array}{l}\text { A geoturizmus a természeti környezet élettelen értékeinek turisztikai célú hasznosítását jelenti. } \\
\text { DowLING (2016) értelmezése szerint az élő természeti bemutató ökoturizmus is a részét képezi, } \\
\text { amelyet a geoparki gyakorlat is alátámaszt. A hasznositás alapegységét a geotópok képezik, } \\
\text { amelyek változatos formában és méretben definiálhatók. A természetvédelemmel együttmüködve cél } \\
\text { az értékek fenntartható bemutatása valamint az oktatási-nevelési jelleg elötérbe helyezése, amely a } \\
\text { turizmus más ágaival összehasonlitva eltérő fejlesztési megközelítést igényel. }\end{array}$ & $\begin{array}{l}\text { HOSE } 2008, \\
\text { DoWLING } 2011,2016, \\
\text { NEWSOME \& DOWLING } \\
2010, \\
\text { KuBALIKOVA } 2013\end{array}$ \\
\hline
\end{tabular}

tartalmazhat (pl. tokaji Nagyhegy — geomorfotóp, kôbányák - geotópok, SzEPESI et al. 2017). Korlátozott vagy tudományos értékkel egyáltalán nem rendelkező objektumok (támfalak, pincék) szintén a geodiverzitás részét képezik (geodiversity sites) és a hazai kategóriák közül az egyedi tájérték fogalom földtudományi jellemzőkkel is rendelkezô objektumaival azonosíthatók.

Az előző fejezetben elmondottak alapján számos módszertani iskola és minôsítő rendszer próbálta a geotópokat kvantitatív módon értékelni. Az idôrendben később publikált módszerek legtöbb esetben a korábbi eredményeket feldolgozva, azokat beépítve, fejlesztve, bővítve léptek tovább.

\section{Minốsítési módszerek kiválasztása}

Az összehasonlító értékeléshez mintegy $60 \mathrm{db}$ a védelem, bemutatás és geoturisztikai szerepkör szempontjából különbözô objektumokat válogattunk (IV. táblázat, 1. ábra). Ezek egy része a tervezett Pannon Vulkán Út (HARANGi et al. 2015, SzEPESI et al. 2017) geotópjait képviseli, míg a második csoport karsztos területek (Bükk) formakincsét (forrás, barlang), valamint földtani alapszelvényeket, ex lege értékeket foglal magába. A módszerek ismertetése előtt hangsúlyozni kell, a választott geotópok mintacsoportja bár az ország területét tekintve nem tekinthetố reprezentatívnak a területi védelem szintjét és geoturisztikai hasznosítás lehetőségeit tekintve azonban megfelelő a hazai helyzetkép megrajzolásához.

Az értékminősító módszerek két fô csoportra bonthatók: a kvantitatív módszerek egyszerú vagy súlyozott értékekkel számszerú minősítést adnak, ahol fô kategóriák összegzett pontértékei alapján a geotóp, geomorfotóp részletes értékelése elvégezhetô (védelem-megőrzés, bemutatás, geoturisztikai hasznosítás). A kvalitatív módszerek csak szöveges jellemzést adnak (WIMBLEDON et al. 1999) esetleg térképi jelkulccsal különböztetnek meg kategóriákat (REYNARD et al. 2016), amely így nehezen áttekinthetố. A kvantitatív módszerek érték kategóriái két fő csoportra oszthatók fel (IIa, IIb táblázat). A fó értékeket a tudományos és hozzáadott értékek, valamint a védettség és potenciális veszélyek alcsoportok és indikátoraik képviselik. A járulékos értékcsoportba a funkcionális és turisztikai alcsoportok és jellemzőik kerültek. Egyes módszerek (BRUSCHI et al. 2011, BRILHA 2016) az indikátorok súlyozásával próbálták hangsúlyozni egyes tényezôk fontosságát.

Az összehasonlító értékeléshez elsőként minden fôbb kutatócsoport (IIa és IIb táblázat, PRALONG 2005, PEREIRA et al. 2007, BRUSCHI et al. 2011, FASSOULAS et al. 2012, FeUILLET \& SOURP 2011, RYBAR 2010) egy-egy kvantitatív módszerével minősítettük az objektum adatbázist. A tanulmány keretei nem teszik lehetôvé, hogy minden módszert részletesen ismertessünk. Az egyes módszerek hasonlósága, az indikátorok ismétlődése miatt végül két kvantitatív módszert választottunk ki a hazai geoturisztikai helyzetkép vázlatos értékeléséhez. Az elsô az egyik legtöbb indikátort tartalmazó, a turisztikai szerepkört is részletesen elemző ún. geotóp minösitési rendszer (geosite assessment model, ERHARTIĆ 2011, VuJIČIĆ et al. 2011, VISNIĆ et al. 2011). A másik, súlyozott indikátorokkal dolgozó módszer (BRILHA 2016), amely kiemelt hangsúlyt fektet a az oktatási és turisztikai hasznosítás, valamint a védelem-veszélyeztetettség kérdéseire. 
IV. táblázat. A vizsgált geotópok/geomorfotópok földtani jellemzői és értékminősítő pontszámaik VuJIČIĆ et al. 2011 és BRILHA 2016 alapján

Table IV. The geological characteristics and rating scores of the investigated eosites/geomorphosites based on assessment methods of VUJIČIC et al. 2011 and BRILHA 2016

\begin{tabular}{|c|c|c|c|c|c|c|c|c|}
\hline \multirow{3}{*}{$\begin{array}{l}\text { Geotóp/ } \\
\text { Geomorfotóp }\end{array}$} & \multirow{3}{*}{ Legfontosabb földtani képződmény (ek) } & \multirow{3}{*}{ Védelem } & \multirow{3}{*}{ Geoturizmus } & \multicolumn{5}{|c|}{ Geotóp minősítési értékkategóriák } \\
\hline & & & & \multirow{2}{*}{$\frac{1 .}{\text { mezö }}$} & \multicolumn{4}{|c|}{2.} \\
\hline & & & & & tud. & okt. & tur. & deg. \\
\hline $\begin{array}{l}\text { 1. Celldömölk, } \\
\text { Ság-hegy }\end{array}$ & $\begin{array}{l}\text { bazaltvulkán belső szerkezete: változatos bazaltvulkáni erupciók } \\
\text { képződményei, kürtő }\end{array}$ & tájvédelmi körzet & $\begin{array}{l}\text { látogatóközp., } \\
\text { tanösvény }\end{array}$ & $\mathrm{M}_{11}$ & I & I & I & II \\
\hline 2. Kissomlyó & $\begin{array}{l}\text { komplex bazaltvulkán: tufagyürün belüli párnaláva, magma- } \\
\text { üledék kölcsönhatás }\end{array}$ & nincs & nincs & $\mathrm{M}_{22}$ & I & II & II & II \\
\hline $\begin{array}{l}\text { 3. Monoszló, } \\
\text { Hegyestü }\end{array}$ & lepusztult bazaltneck, oszlopos elválási szerkezet & nemzeti park & $\begin{array}{l}\text { geopark, földtani } \\
\text { bemutatóhely, } \\
\text { turistaút }\end{array}$ & $\mathrm{M}_{12}$ & II & II & I & III \\
\hline $\begin{array}{l}\text { 4. Tihany, } \\
\text { Barátlakások }\end{array}$ & $\begin{array}{l}\text { maar vulkán proximális része, típusos maar, keresztrétegzett } \\
\text { torlóár-üledékek, lávabomba bezsákolódás }\end{array}$ & nemzeti park & $\begin{array}{l}\text { geopark, } \\
\text { látogatóközp. } \\
\text { tanösvény }\end{array}$ & $\mathrm{M}_{22}$ & I & II & I & II \\
\hline $\begin{array}{l}\text { 5. Zalahaláp, } \\
\text { Haláp }\end{array}$ & $\begin{array}{l}\text { bazalt tanúhegy és bányaudvar: oszlopos elválás, zeolitos } \\
\text { ásványtársulások }\end{array}$ & & geopark, tanösvény & $\mathrm{M}_{23}$ & II & II & II & I \\
\hline $\begin{array}{l}\text { 6. Szentbékkálla, } \\
\text { felhagyott kőfejtö, }\end{array}$ & $\begin{array}{l}\text { bazaltos piroklasztár-lerakódás: gázkiszökési csatornák, } \\
\text { ultrabázisos köpenyxenolitok, alaphegységi litoklasztok, fedö } \\
\text { torlóár és maar üledékek }\end{array}$ & nemzeti park, & $\begin{array}{l}\text { geopark, földtani } \\
\text { bemutatóhely }\end{array}$ & $\mathrm{M}_{23}$ & II & II & II & II \\
\hline $\begin{array}{l}\text { 7. Szent György- } \\
\text { hegy }\end{array}$ & $\begin{array}{l}\text { erodált pliocén bazalt tanúhegy, morfológiai inverzió, } \\
\text { bazaltorgonák, csuszamlásos formák }\end{array}$ & nemzeti park & $\begin{array}{l}\text { geopark, } \\
\text { tanösvény, turistaút }\end{array}$ & $\mathrm{M}_{22}$ & II & II & I & III \\
\hline $\begin{array}{l}\text { 8. Pákozdi Ingó- } \\
\text { kövek }\end{array}$ & $\begin{array}{l}\text { Karbon gránit mállásával és eróziójával létrejött gyapjúzsák } \\
\text { alakú ingókövek }\end{array}$ & $\begin{array}{l}\text { természet-védelmi } \\
\text { ter. }\end{array}$ & tanösvény & $\mathrm{M}_{23}$ & II & I & II & III \\
\hline $\begin{array}{l}\text { 9. Csopak, perm- } \\
\text { triász határszelvény }\end{array}$ & $\begin{array}{l}\text { vörös perm homokkő és a rátelepülö alsó-triász aleurolit, } \\
\text { homokkő és dolomit földtani alapszelvénye }\end{array}$ & $\begin{array}{l}\text { természeti } \\
\text { emlék }\end{array}$ & $\begin{array}{l}\text { földtudományi } \\
\text { ismeretterjesztő } \\
\text { tájékoztató tábla }\end{array}$ & $\mathrm{M}_{23}$ & II & II & II & III \\
\hline $\begin{array}{l}\text { 10. Tata Kálvária } \\
\text { domb }\end{array}$ & $\begin{array}{l}\text { a Pelsói-egység mezozoikumának egyik legfontosabb földtani } \\
\text { alapszelvénye (200-67 millió év). Triász-kréta mészkö } \\
\text { formációk (Dachsteini, Pisznicei Tüzkövesárki), radiolarit, } \\
\text { régészeti lelőhely }\end{array}$ & $\begin{array}{l}\text { természet-védelmi } \\
\text { terület }\end{array}$ & $\begin{array}{l}\text { földtani bemutató- } \\
\text { hely, szakvezetés }\end{array}$ & $\mathrm{M}_{11}$ & I & I & I & III \\
\hline $\begin{array}{l}\text { 11. Gánt } \\
\text { bauxitbánya }\end{array}$ & $\begin{array}{l}\text { felhagyott külszíni bánya: a triász Födolomit karsztos } \\
\text { mélyedéseibe települö felsö-kréta-eocén kavicsos és iszapszerü } \\
\text { bauxitrétegek, }\end{array}$ & tájvédelmi körzet & $\begin{array}{l}\text { bemutatóhely, } \\
\text { tanösvény }\end{array}$ & $\mathrm{M}_{22}$ & III & II & I & III \\
\hline $\begin{array}{l}\text { 12. Visegrádi- } \\
\text { hegység } \\
\text { Holdvilágárok }\end{array}$ & $\begin{array}{l}\text { miocén andezites piroklasztitba mélyülö szurdokvölgy, akkréciós } \\
\text { lapilli tartalmú rétegek, gránáttartalmú riodácit, andezites } \\
\text { ignimbrit, blokk és hamuár üledékek }\end{array}$ & nemzeti park & turistaút & $\mathrm{M}_{23}$ & III & II & III & I \\
\hline $\begin{array}{l}\text { 13. Visegrád } \\
\text { Várhegy }\end{array}$ & $\begin{array}{l}\text { összeomlott rétegvulkáni szerkezet: andezites törmelékár- } \\
\text { képződmények }\end{array}$ & nemzeti park & $\begin{array}{l}\text { vár (földtud. ism. } \\
\text { terjesztés nélkül) }\end{array}$ & $\mathrm{M}_{22}$ & II & I & $\mathrm{I}$ & II \\
\hline $\begin{array}{l}\text { 14. Dobogókő } \\
\text { Thirring-sziklák }\end{array}$ & $\begin{array}{l}\text { andezit anyagú sziklaalakzatok: morfológiai inverzióval } \\
\text { kipreparálódott blokk és hamuár üledékek }\end{array}$ & nemzeti park, & turistaút & $\mathrm{M}_{23}$ & III & II & II & III \\
\hline $\begin{array}{l}\text { 15. Nógrádi } \\
\text { várhegy }\end{array}$ & erodált dácit lávadóm, gránát tartalmú dácit & nincs & turistaút & $\mathrm{M}_{22}$ & III & II & II & III \\
\hline $\begin{array}{l}\text { 16. Cserhát, Bér } \\
\text { (andezit-csúszda) }\end{array}$ & andezit neck: egyedi, homorú, oszlopos elválású andezit & $\begin{array}{l}\text { természeti emlék, } \\
\text { tájvédelmi körzet }\end{array}$ & $\begin{array}{l}\text { geopark, földtani } \\
\text { bemutatóhely }\end{array}$ & $\mathrm{M}_{23}$ & II & II & II & III \\
\hline $\begin{array}{l}\text { 17. Ipolytarnóc } \\
\text { Ősmaradványok } \\
\text { TT. }\end{array}$ & $\begin{array}{l}\text { miocén lábnyomos homokkő és ignimbrit: laza ignimbrit (faszén } \\
\text { töredékek), folyóvízi üledékekben megőrzött lábnyomok, } \\
\text { kovásodott fatörzsek, }\end{array}$ & tájvédelmi körzet, & $\begin{array}{l}\text { geopark, } \\
\text { látogatóközpont, } \\
\text { tanösvény, turistaút }\end{array}$ & $\mathrm{M}_{11}$ & I & II & II & III \\
\hline $\begin{array}{l}\text { 18. Kazár } \\
\text { riolittufa }\end{array}$ & $\begin{array}{l}\text { miocén (Gyulakeszi) riolittufa felszínen a kialakult eróziós } \\
\text { makro és mikro formakincs }\end{array}$ & nincs & turistaút & $\mathrm{M}_{23}$ & II & II & II & I \\
\hline 19. Tar kőfejtő & laza miocén ignimbrit, gázkifúvási csatornákkal & nincs & nincs & $\mathrm{M}_{33}$ & II & II & II & III \\
\hline $\begin{array}{l}\text { 20. Ilona-völgy } \\
\text { vízesesés }\end{array}$ & $\begin{array}{l}\text { üledékes kőzetekre települő miocén andezit és a legnagyobb } \\
\text { esésű vulkáni kőzeten kialakult vízesés }\end{array}$ & tájvédelmi körzet & tanösvény & $\mathrm{M}_{23}$ & III & II & II & III \\
\hline $\begin{array}{l}\text { 21. Tarjánka } \\
\text { szurdok }\end{array}$ & $\begin{array}{l}\text { andezites piroklasztitba mélyülő szurdokvölgy: láva, } \\
\text { lávabreccsára települő szórt freatomagmás üledékek, gömbhéjas } \\
\text { elválású blokkokkal }\end{array}$ & tájvédelmi körzet & nincs & $\mathrm{M}_{21}$ & III & II & II & III \\
\hline 22. Siroki várhegy & $\begin{array}{l}\text { vastag hullott és piroklaszt-ár terítésekbôl felépülö miocén } \\
\text { ignimbritösszlet, szelektív erózió (Barát és Apáca sziklák) }\end{array}$ & természeti emlék & $\begin{array}{l}\text { vár (földtud. ism. } \\
\text { terjesztés nélkül) }\end{array}$ & $\mathrm{M}_{22}$ & III & II & II & II \\
\hline $\begin{array}{l}\text { 23. Aggtelek } \\
\text { Ördögszántás }\end{array}$ & $\begin{array}{l}\text { triász Wettersteini Mészkövön kialakult fedetlen karszt, fák } \\
\text { gyökerei által kioldott karokkal, víznyelö eltömődésével létrejött } \\
\text { tóval }\end{array}$ & nemzeti park & tanösvény & $\mathrm{M}_{22}$ & III & II & II & II \\
\hline $\begin{array}{l}\text { 24. Vörös-tói } \\
\text { Medve-sziklák }\end{array}$ & $\begin{array}{l}\text { triász Steinalmi Mészkővön kialakult paleokarszt formakincs, } \\
\text { kréta-eocén bauxitos mállástermék, típusos dolina töbörtó } \\
\text { (földtani alapszelvény) }\end{array}$ & nemzeti park & tanösvény & $M_{12}$ & I & II & II & III \\
\hline $\begin{array}{l}\text { 25. Szögliget } \\
\text { szádvári szelvény }\end{array}$ & $\begin{array}{l}\text { triász pelágkus mészkőformációk (Hallstatti, Pötscheni) földtani } \\
\text { alapszelvénye az Aggtelek-Rudabányai-hegységben (földtani } \\
\text { alapszelvény) }\end{array}$ & nemzeti park & turistaút & $\mathrm{M}_{23}$ & II & II & II & III \\
\hline $\begin{array}{l}\text { 26. Szalonna } \\
\text { Telekes-oldal }\end{array}$ & $\begin{array}{l}\text { az Aggtelek-Rudabányai-hegység jura rétegsorának } \\
\text { alapszelvénye, medence és kontinetális lejtő üledékei } \\
\text { (olisztosztróma, földtani alapszelvény). }\end{array}$ & nemzeti park & nincs & $\mathrm{M}_{23}$ & II & II & II & III \\
\hline $\begin{array}{l}\text { 27. Upponyi- } \\
\text { szoros }\end{array}$ & $\begin{array}{l}\text { paleozoos mészkő formációkban (Upponyi, Abodi) kialakult } \\
\text { völgyszoros, a völgyben a Lázbérci víztározóval }\end{array}$ & tájvédelmi körzet & tanösvény & $\mathrm{M}_{12}$ & II & II & II & II \\
\hline
\end{tabular}


IV. táblázat. Folytatás

Table IV. Continuation

\begin{tabular}{|c|c|c|c|c|c|c|c|c|}
\hline \multirow{3}{*}{$\begin{array}{c}\text { Geotóp/ } \\
\text { Geomorfotóp }\end{array}$} & \multirow{3}{*}{ Legfontosabb földtani képződmény (ek) } & \multirow{3}{*}{ Védelem } & \multirow{3}{*}{ Geoturizmus } & \multicolumn{5}{|c|}{ Geotóp minösitési értékkategóriák } \\
\hline & & & & \multirow{2}{*}{$\frac{1 .}{\text { mezö }}$} & \multicolumn{4}{|c|}{2.} \\
\hline & & & & & tud. & okt. & tur. & deg. \\
\hline $\begin{array}{l}\text { 28. Upponyi- } \\
\text { hegység Damasa- } \\
\text { szakadék }\end{array}$ & $\begin{array}{l}\text { andezites piroklasztitösszletben kialakult szurdokvölgy, fiatal } \\
\text { blokkos csuszamlás és álbarlangrendszer }\end{array}$ & tájvédelmi körzet & turistaút & $\mathrm{M}_{23}$ & III & II & II & III \\
\hline $\begin{array}{l}\text { 29. Nagyvisnyó, } \\
\text { Mihalovits-kőfejtő }\end{array}$ & $\begin{array}{l}\text { perm bitumenes mészkö (Nagyvisnyói) földtani alapszelvény, } \\
\text { jellegzetes gastropoda, brachiopoda, crinoidea vázelemekkel }\end{array}$ & & nincs & $\mathrm{M}_{21}$ & II & II & II & III \\
\hline $\begin{array}{l}\text { 30. Ablakos-kö- } \\
\text { völgy }\end{array}$ & $\begin{array}{l}\text { karbon-triász rétegsorba mélyülő szurdokvölgy a Bükkben, felső } \\
\text { részén a Gerennavári Mészkő függőlegesre állított bordáival }\end{array}$ & nemzeti park & nincs & $\mathrm{M}_{31}$ & II & II & II & III \\
\hline 31. Dédes várhegy & $\begin{array}{l}\text { triász mészkőtakaró eróziós roncsa a perm sekélytengeri } \\
\text { rétegsoron }\end{array}$ & nemzeti park & turistaút & $\mathrm{M}_{21}$ & III & III & II & III \\
\hline 32. Csondró-völgy & $\begin{array}{l}\text { alsó-triász (Gerennnavári, Ablakoskővölgyi) mészkőben kialakult } \\
\text { szurdokvölgy a Bükk északi oldalán, forrásmészkő-kiválások, } \\
\text { Odvas-köi barlangszállás }\end{array}$ & nemzeti park & turistaút & $\mathrm{M}_{13}$ & III & II & II & III \\
\hline $\begin{array}{l}\text { 33. Bükk-fennsík } \\
\text { Nagy-Mezö }\end{array}$ & $\begin{array}{l}\text { középső-triász (Bükkfennsíki) mészkövön kialakult típusos } \\
\text { oldásos karszt-formakincs (víznyelök, dolinák, uvalák) }\end{array}$ & nemzeti park & tanösvény & $\mathrm{M}_{12}$ & III & II & II & III \\
\hline $\begin{array}{l}\text { 34. Zsidó-rét } \\
\text { Mohos-töbör }\end{array}$ & $\begin{array}{l}\text { A Bükk-fennsík legnagyobb, időszakosan víznyelöként is müködő } \\
\text { dolinája }\end{array}$ & nemzeti park & tanösvény & $\mathrm{M}_{23}$ & III & II & II & III \\
\hline 35. Tar-kö & $\begin{array}{l}\text { triász mészkövön kialakult krioplanációs fal. A fennsík peremén } \\
\text { tektonikai és eróziós hatásra kialakult „Bükki kövek" } \\
\text { vonulatának része }\end{array}$ & nemzeti park & tanösvény & $\mathrm{M}_{23}$ & III & II & II & III \\
\hline $\begin{array}{l}\text { 36. Udvar-kö } \\
\text { szakadéktöbör }\end{array}$ & felső-triász mészkőben kialakult beszakadt víznyelőbarlang & nemzeti park & turistaút & $\mathrm{M}_{23}$ & III & II & II & III \\
\hline $\begin{array}{l}\text { 37. Hór-völgy } \\
\text { mészkóbánya }\end{array}$ & felső-triász zátony mészkő (Bervai M.F.) földtani alapszelvénye & nemzeti park & $\begin{array}{l}\text { tanösvény, } \\
\text { látogatóközpont }\end{array}$ & $\mathrm{M}_{22}$ & II & II & II & III \\
\hline 38. Suba-lyuk & $\begin{array}{l}\text { A Bervai Mészkő anyagába mélyülö rombarlang, a } \\
\text { neandervölgyi ember kultúrájának régészeti lelőhhelye }\end{array}$ & nemzeti park & $\begin{array}{l}\text { tanösvény, } \\
\text { látogatóközpont }\end{array}$ & $\mathrm{M}_{22}$ & III & II & II & III \\
\hline 39. Szeleta-barlang & $\begin{array}{l}\text { triász mészkőbe mélyülö inaktív forrásbarlang, az első } \\
\text { magyarországi barlangi ásatások helyszíne a szeleta kultúra } \\
\text { névadója }\end{array}$ & nemzeti park & túristaút & $\mathrm{M}_{22}$ & III & II & II & III \\
\hline $\begin{array}{l}\text { 40. Lillafüred } \\
\text { Anna-barlang }\end{array}$ & $\begin{array}{l}\text { a Szinva mésztufa kúpjában kialakult természetes üregrendszer, } \\
\text { mellette időszakosan működő vízeséssel }\end{array}$ & nemzeti park & $\begin{array}{l}\text { földtani } \\
\text { bemutatóhely }\end{array}$ & $\mathrm{M}_{11}$ & II & II & II & III \\
\hline $\begin{array}{l}\text { 41. Szilvásvárad } \\
\text { Fátyol-vizesés }\end{array}$ & $\begin{array}{l}\text { a Szalajka-patak vízéböl kicsapódó mésztufából felépülö } \\
\text { gátrendszer, } 18 \text { terasszal }\end{array}$ & nemzeti park & tanösvény & $\mathrm{M}_{12}$ & II & II & I & III \\
\hline $\begin{array}{l}\text { 42. Vörös-kö- } \\
\text { forrás }\end{array}$ & $\begin{array}{l}\text { a bükki időszakosan (február-április) müködő karsztforrások } \\
\text { képviselője }\end{array}$ & nemzeti park & tanösvény & $\mathrm{M}_{23}$ & III & II & II & III \\
\hline $\begin{array}{l}\text { 43. Szarvaskö } \\
\text { Tóbérci kőfejtő }\end{array}$ & $\begin{array}{l}\text { jura gabbró, és mélytengeri agyagpala, kontakt szaruszirt, } \\
\text { granodiorit, vetőbreccsa }\end{array}$ & $\begin{array}{l}\text { Nemzeti Park, } \\
55 / 2015 \text { alapszelv }\end{array}$ & $\begin{array}{l}\text { földtani } \\
\text { bemutatóely és } \\
\text { tanösvény }\end{array}$ & $\mathrm{M}_{23}$ & I & II & II & III \\
\hline $\begin{array}{l}\text { 44. Bogács } \\
\text { Vénhegy }\end{array}$ & $\begin{array}{l}\text { miocén összesült fiammés tufa, és laza ignimbrit, kevert } \\
\text { horzsakő-salak tartalmú piroklasztár összlet }\end{array}$ & természeti emlék & turistaút & $\mathrm{M}_{23}$ & II & II & II & II \\
\hline $\begin{array}{l}\text { 45. Cserépfalu } \\
\text { Ördögcsúszda }\end{array}$ & miocén laza ignimbriten kialakult eróziós tufafelszín és kaptárkő & nemzeti park & $\begin{array}{l}\text { tanösvény, } \\
\text { látogatóközp. }\end{array}$ & $\mathrm{M}_{22}$ & II & II & II & II \\
\hline $\begin{array}{l}\text { 46. Szomolya } \\
\text { kaptárkövek }\end{array}$ & $\begin{array}{l}\text { miocén laza ignimbriten kialakult eróziós tufafelszín és } \\
\text { kaptárkőcsoport }\end{array}$ & $\begin{array}{l}\text { természetvédelmi } \\
\text { terület }\end{array}$ & tanösvény & $\mathrm{M}_{22}$ & II & II & II & III \\
\hline $\begin{array}{l}\text { 47. Mangó-tetö } \\
\text { kaptárkö }\end{array}$ & $\begin{array}{l}\text { miocén laza ignimbriten kialakult eróziós tufafelszín és } \\
\text { kaptárkőcsoport }\end{array}$ & természeti emlék & turistaút & $\mathrm{M}_{23}$ & III & II & II & III \\
\hline 48. Kőporlyuk & $\begin{array}{l}\text { miocén laza ignimbrit és rátelepülö akkréciós lapilli tartalmú } \\
\text { tufaösszlet }\end{array}$ & nincs & $\begin{array}{l}\text { tanösvény, } \\
\text { látogatóközp. }\end{array}$ & $\mathrm{M}_{32}$ & III & II & II & III \\
\hline $\begin{array}{l}\text { 49. Cserépfalu } \\
\text { Nyomó-hegy }\end{array}$ & $\begin{array}{l}\text { miocén oszlopos elválású összesült ignimbriten kialakult, déli } \\
\text { irányban kibillent aszimmetrikus réteglépcsö }\end{array}$ & nincs & nincs & $\mathrm{M}_{22}$ & II & II & II & III \\
\hline 50. Vizsoly köfejtő & $\begin{array}{l}\text { miocén laza ignimbritösszlet, a hegységben egyedülálló, széles } \\
\text { gázkifúvási csatornák és horzsakőblokkok }(\emptyset 30-50 \mathrm{~cm})\end{array}$ & nincs & nincs & $\mathrm{M}_{23}$ & II & II & II & III \\
\hline 51. Fűzér várhegy & miocén dácitneck oszlopos elválású kürtőkitöltés & tájvédelmi körzet & nincs & $\mathrm{M}_{22}$ & III & II & I & II \\
\hline $\begin{array}{l}52 \text { Telkibánya, } \\
\text { Király-hegy }\end{array}$ & $\begin{array}{l}\text { miocén, hólyagüreges riodácit lávadóm hidrotermálisan bontott, } \\
\text { kovás periglaciális törmelékanyaga }\end{array}$ & tảjvédelmi körzet & tanösvény & $\mathrm{M}_{22}$ & III & III & II & II \\
\hline $\begin{array}{l}\text { 53. Erdőbénye } \\
\text { Mulató-hegy }\end{array}$ & $\begin{array}{l}\text { miocén szubvulkáni andezittest (lakkolit) kihülési elválási } \\
\text { rendszere, összesült riolittufa kontakt, egyedi ásvány paragenezis }\end{array}$ & nincs & nincs & $\mathrm{M}_{23}$ & III & II & II & III \\
\hline $\begin{array}{l}\text { 54. Tokaj Lebuj } \\
\text { perlitfal }\end{array}$ & $\begin{array}{l}\text { miocén riolitos lávaár kontaktöve: marekanitos perlit, } \\
\text { nagyméretű litofizák, összesülés a kontaktövben }\end{array}$ & tájvédelmi körzet & nincs & $\mathrm{M}_{22}$ & III & II & II & II \\
\hline $\begin{array}{l}\text { 55. Megyer-hegy } \\
\text { kőfejtő }\end{array}$ & $\begin{array}{l}\text { miocén ignimbrit és malomkőbánya héjtöredékes üledékekkel } \\
\text { tagolt szubmarin horzsakőgazdag ignimbrit, intenzív } \\
\text { hidrotermális elbontás }\end{array}$ & $\begin{array}{l}\text { természetvédelmi } \\
\text { terület }\end{array}$ & tanösvény & $\mathrm{M}_{22}$ & II & I & II & III \\
\hline $\begin{array}{l}\text { 56. Tokaj Finánc- } \\
\text { domb }\end{array}$ & $\begin{array}{l}\text { a tokaji Nagy-hegy dácitjára boruló lösztakaró feltárása a Tisza } \\
\text { és a Bodrog találkozása fölött }\end{array}$ & egyedi tájérték & nincs & $\mathrm{M}_{32}$ & III & II & II & II \\
\hline $\begin{array}{l}\text { 57. Hétszőlö } \\
\text { tanösvény }\end{array}$ & $\begin{array}{l}\text { a Hétszőlő birtok szölötermesztési tradíciókat és a Tokaji } \\
\text { borvidék kulturális örökségét bemutató tanösvénye (UNESCO } \\
\text { világörökség) }\end{array}$ & egyedi tájérték & tanösvény & $\mathrm{M}_{22}$ & III & II & II & II \\
\hline
\end{tabular}


IV. táblázat. Folytatás

Table IV. Continuation

\begin{tabular}{|c|c|c|c|c|c|c|c|c|}
\hline \multirow{3}{*}{$\begin{array}{l}\text { Geotóp/ } \\
\text { Geomorfotóp }\end{array}$} & \multirow{3}{*}{ Legfontosabb földtani képződmény (ek) } & \multirow{3}{*}{ Védelem } & \multirow{3}{*}{ Geoturizmus } & \multicolumn{5}{|c|}{ Geotóp minősitési értékkategóriák } \\
\hline & & & & \multirow{2}{*}{$\frac{1 .}{\text { mezö }}$} & \multicolumn{4}{|c|}{2} \\
\hline & & & & & tud. & okt. & tur. & deg. \\
\hline $\begin{array}{l}\text { 58. Hercegkút } \\
\text { Gombos-hegyi } \\
\text { pincesor }\end{array}$ & $\begin{array}{l}\text { a Tokaj-hegyaljai borvidék Miocén ignimbritbe mélyülő, önálló } \\
\text { UNESCO világörökségi objektumként nyilvántartásba pincesora }\end{array}$ & & nincs & $\mathrm{M}_{22}$ & III & II & II & II \\
\hline $\begin{array}{l}\text { 59. Abaújszántó } \\
\text { pincesor }\end{array}$ & $\begin{array}{l}\text { a Tokaj-hegyaljai borvidék kultúrtáji tradíciókat őrző pincesora, } \\
\text { részben miocén riolit szálkőzetben kialakítva védelem nélkül }\end{array}$ & & nincs & $\mathrm{M}_{22}$ & III & II & II & II \\
\hline $\begin{array}{l}\text { 60. Abaújszántó } \\
\text { szőlőteraszok }\end{array}$ & $\begin{array}{l}\text { a Sátor-hegy oldalában a hegyoldal miocén riolit kőzetanyagából } \\
\text { szárazon megrakott, a szőlőművelés számára kialakitott } \\
\text { agroteraszok }\end{array}$ & & nincs & $\mathrm{M}_{33}$ & III & III & III & II \\
\hline $\begin{array}{l}\text { 61. Tálya Patócs- } \\
\text { hegy obalák } \\
\text { (sáncok) }\end{array}$ & $\begin{array}{l}\text { az erodált miocén lávadóm fellazult felszinét a szőlőművelés } \\
\text { során a törmelékből kialakított, parcellákat elválasztó kősáncok } \\
\text { tagolják. } \\
\text { A lejtôsztyepprét és a kapcsolódó kőtenger természetvédelmi } \\
\text { terület }\end{array}$ & $\begin{array}{l}\text { természetvédelmi } \\
\text { terület }\end{array}$ & nincs & $\mathrm{M}_{33}$ & III & III & III & II \\
\hline 62. Kaszonyi-hegy & $\begin{array}{l}\text { felhagyott kőfejtő és fészkelöhely egyedi litoklasztokban gazdag, } \\
\text { lávaszerüen újraolvadt miocén reoignimbrit }\end{array}$ & $\begin{array}{l}\text { természetvédelmi } \\
\text { terület }\end{array}$ & nincs & $\mathrm{M}_{21}$ & III & III & III & III \\
\hline
\end{tabular}

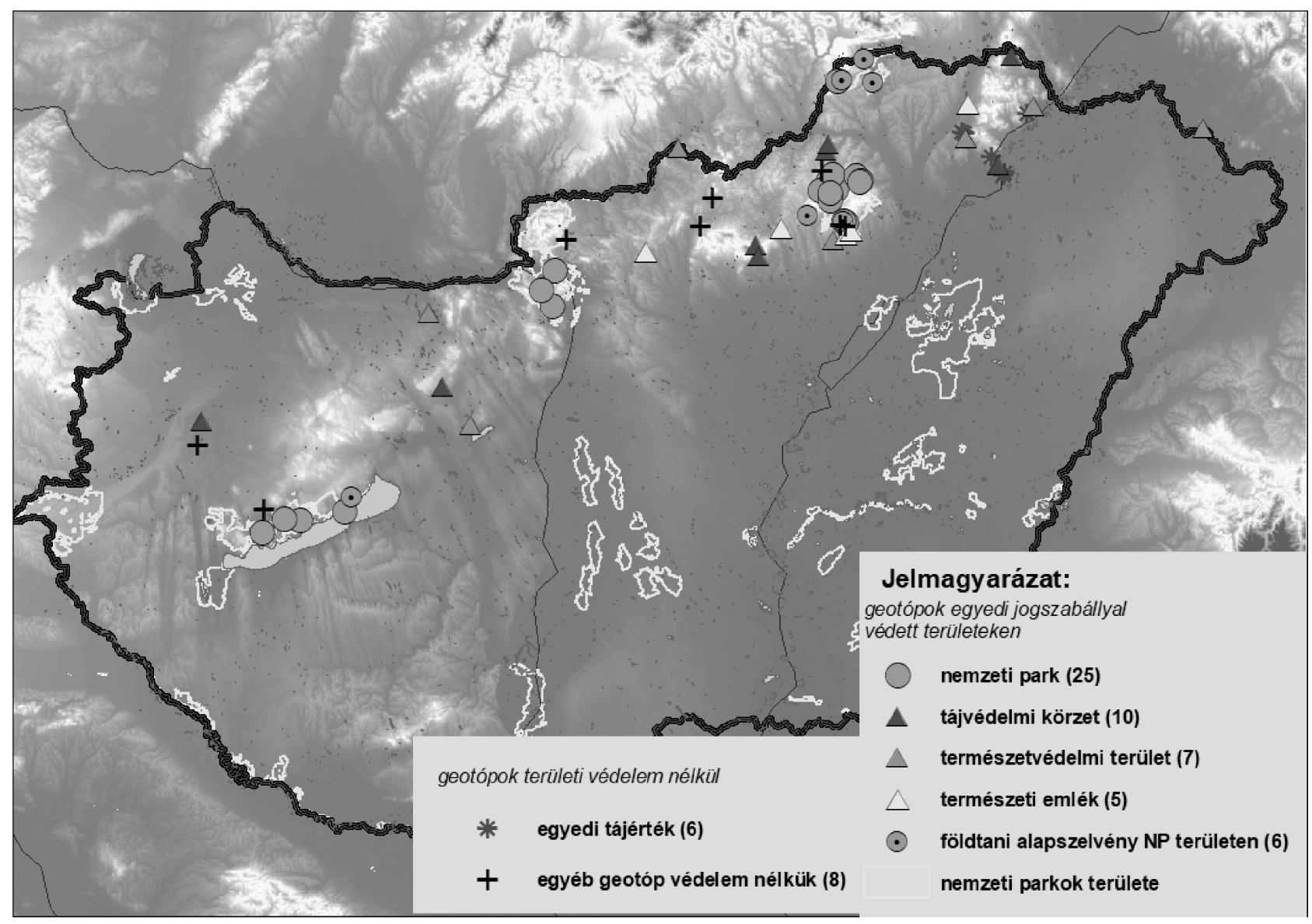

1. ábra. A vizsgált földtudományi értékek földrajzi elhelyezkedése. A védett természeti értékek csoportositása a hazai természetvédelemi gyakorlat rendszerét követi

Figure 1. Location of the examined geoheritage values. The grouping follows the domestic nature conservation practice

\section{Geotóp minốsítés rendszerek}

A szerb geográfusok által létrehozott minősítési rendszer szorosan támaszkodik az addig publikált értékelések eredményeire (BRUSCHI \& CENDRERO 2005, PRALONG 2005, REYNARD et al. 2007, PEREIRA et al. 2007, Zouros 2007, SERRANO \& GonZALES-TruEba 2005). Az indikátorok két fö csoportját a fô és hozzáadott értékek jelentik. A fő értékek 12 minősítő jellemzőjét három csoportba sorolták, amelyeket a tudományos/oktatási $\left(\mathrm{V}_{\mathrm{TO}}\right.$ : ritkaság, reprezentativitás, tudományos ismertség, bemutathatóság), a tájképilesztétikai $\left(\mathrm{V}_{\mathrm{TE}}\right.$ :megfigyelési pontok száma, terület, tájkép, környezet) és a védelem $\left(\mathrm{V}_{\mathrm{v}}\right.$ :jelenlegi állapot, védelem fokozata, sérülékenység, látogatók maximális létszáma) kategó- 
riák képviselnek. A második fő csoportba a hozzáadott értékek 15 indikátora tartozik. A funkcionális értékek a geotópok környezetét minősítik ( $\mathrm{V}_{\mathrm{FK}}$ : megközelíthetőség, úthálózat minősége, további természeti és antropogén értékek, vonzáskörzet), míg a turisztikai értékek ( $\mathrm{V}_{\mathrm{TUR}}$ : promóció, vezetett túrák száma, látogatóközpont távolsága, interpretáció minősége, éves látogatószám, geoturisztikai infrastruktúra, szállás-étkezési lehetôségek) alcsoport már a tényleges turisztikai szerepkört vizsgálja. Az egyes geotópok minősítése során az indikátorok 0-1 közötti (0-0,250,5-0,75-1) értéket vehetnek föl. Az egyes alcsoportok összesítése adja meg a geotóp fô és hozzáadott értékszámát.

$\mathrm{GMR}=$ Fő értékek $\left(\mathrm{V}_{\mathrm{TO}}+\mathrm{V}_{\mathrm{TE}}+\mathrm{V}_{\mathrm{V}}\right)+$ Hozzáadott értékek $\left(\mathrm{V}_{\mathrm{FK}}+\mathrm{V}_{\mathrm{TUR}}\right)$

Az indikátorok értéke alapján a fóérték maximálisan 12, a hozzáadott érték 15 pontszámot vehet fel. Ezt egy koordinátarendszerben ábrázolva egy 9 részre osztott mátrixot kapunk, amelyben a geotóp pozíciója egyértelmúen megadja tudományos értékét, turisztikai hasznosítási lehetőségeit.

A második módszert a ProGEO (The European Association for Conservation of the Geological Heritage) elnöke, BRILHA (2016) az eddigi minősítési módszerek összegzéseként, esettanulmány nélkül publikálta. Az indikátorok ( $V$. táblázat) 0-4 pont közötti értéket vehetnek föl, amelyek 4 fó csoportba rendezve (tudományos érték, oktatási és turisztikai potenciál, degradációs veszély) súlyozva értékelhetők. Az indikátorok egy része eltérô súlyozási faktorral több értékelési csoportnál is szerepet kapott, de a faktorok csoportösszege (indikátorszámtól függetlenül) minden esetben 100. A végsô pontszámok maximuma 400. A degradációs kockázatok esetében az értéke- lési pontszám alapján kicsi, közepes és magas veszélyeztetettségi kategóriákat állapított meg (V. táblázat).

\section{Eredmények}

A geotóp minősítési rendszerek egyik legfontosabb problémája a szubjektivitás, amely egyes geotópok tényleges szerepkörénél magasabb értékelési pontszámaiban jelentkezhet. A tanulmány szerzőinek földtani (kôzettan, geokémia, vulkanológia) és földrajzi (tájvédelem, talajtan, geomorfológia, oktatási szakmódszertan) kutatási tapasztalatai a földtudományok elég széles területét képviseli. A szubjektivitás problémáját a szerzók a geotópok listájának véglegesítése után egymástól teljesen független értékelési munkával próbálták csökkenteni. Az eredményeket összesítve és értékelve alakult ki a végsô minôsítő pontérték.

\section{Geotóp minốsítés I. (VuJIČIĆ et al. 2011)}

A fő értékek pontszáma a tudományos, tájképi és védelmi sajátosságok összege (2. ábra, $a, b)$. A tudományosoktatási értékszám $\left(\mathrm{V}_{\mathrm{TO}}\right)$ esetében a ritkaság, reprezentativitás, a bemutathatóság és a megjelent publikációk minősége eltérô súllyal estek latba. A tájképi-esztétikai érték $\left(\mathrm{V}_{\mathrm{TE}}\right)$ és a védelem szintje $\left(\mathrm{V}_{\mathrm{V}}\right)$ egyaránt a fő értékszámokat növelte. A legmagasabb fó értékszámú geotópok (Ság-hegy, Ipolytarnóc) ritkaságuknak, tájképi értékeiknek, oktatási bemutathatóságának és gyakran több évtizedes, széles körű tudományos munkának köszönhetően nemzetközileg is ismert referencia objektumok. A 2015-ben a World Geomorphological Landscapes sorozatban megjelent Landscapes

V. táblázat. Geotóp értékelés indikátorai és súlyozási faktorai BRILHA (2016) rendszerében

Table V. Indicators and weight scores used in geosite assessment method of BRILHA 2016

\begin{tabular}{|c|c|c|c|c|c|c|c|}
\hline Tudományos érték & Súly & Oktatási potenciál & Súly & Turisztikai potenciál & Súly & $\begin{array}{l}\text { Degradációs } \\
\text { kockázatok }\end{array}$ & Súly \\
\hline Reprezentativitás & 30 & sérülékenység & 10 & sérülékenység & 10 & $\begin{array}{l}\text { a földtani értékek } \\
\text { károsodása }\end{array}$ & 35 \\
\hline Alapszelvény & 20 & megközelíthetőség & 10 & megközelíthetőség & 10 & $\begin{array}{l}\text { leromlást okozó } \\
\text { területek/tényezők } \\
\text { közelsége }\end{array}$ & 20 \\
\hline Tudományos ismertség & 5 & korlátozások & 5 & korlátozások & 5 & védelem szintje & 20 \\
\hline Sértetlenség & 15 & biztonság & 10 & biztonság & 10 & megközelíthetöség & 15 \\
\hline Geodiverzitás & 5 & logisztika & 5 & logisztika & 5 & népsürüség & 10 \\
\hline Ritkaság & 15 & népsürüség & 5 & népsürüség & 5 & összesen & 100 \\
\hline Korlátozások & 10 & egyéb érték & 5 & egyéb érték & 5 & & \\
\hline \multirow[t]{7}{*}{ Összesen } & 100 & látvány & 5 & látvány & 15 & & pont érték \\
\hline & & egyediség & 5 & egyediség & 10 & kicsi (III) & $<200$ \\
\hline & & beláthatóság & 10 & beláthatóság & 5 & közepes (II) & $201-300$ \\
\hline & & $\begin{array}{l}\text { didaktikai } \\
\text { potenciál }\end{array}$ & 20 & $\begin{array}{l}\text { bemutathatósági } \\
\text { potenciál }\end{array}$ & & nagy (I) & $301-400$ \\
\hline & & geodiverzitás & 10 & gazdasági fejlettség & 10 & & \\
\hline & & Összesen & 100 & $\begin{array}{l}\text { rekreációs központok } \\
\text { távolsága }\end{array}$ & 5 & & \\
\hline & & & & összesen & 100 & & \\
\hline
\end{tabular}


and Landforms of Hungary (Lóczy 2015) alapján több objektum nemzetközi ismertsége nőtt (pl. Upponyi-szoros, Megyer-hegy). A tudományos megismerés alacsonyabb szintjén álló geotópok (pl. kőfejtők), és geodiverzitás objektumok (források, kaptárkövek) értékeit negatívan befolyásolta az emberi behatás mértéke (pl. felhagyott szőló- teraszok), amely a tájképi-esztétikai érték csökkenését vonta maga után. Hasonló irányban befolyásolta az értékszámokat a védelem hiánya (Vizsoly - kőfejtő, Kőporlyuk Cserépfalu).

A hozzáadott értékek közül az elsố csoportot a funkcionális jellemző́k adják $\left(\mathrm{V}_{\mathrm{FN}}\right)$, amelyek nem elsődleges turisz-

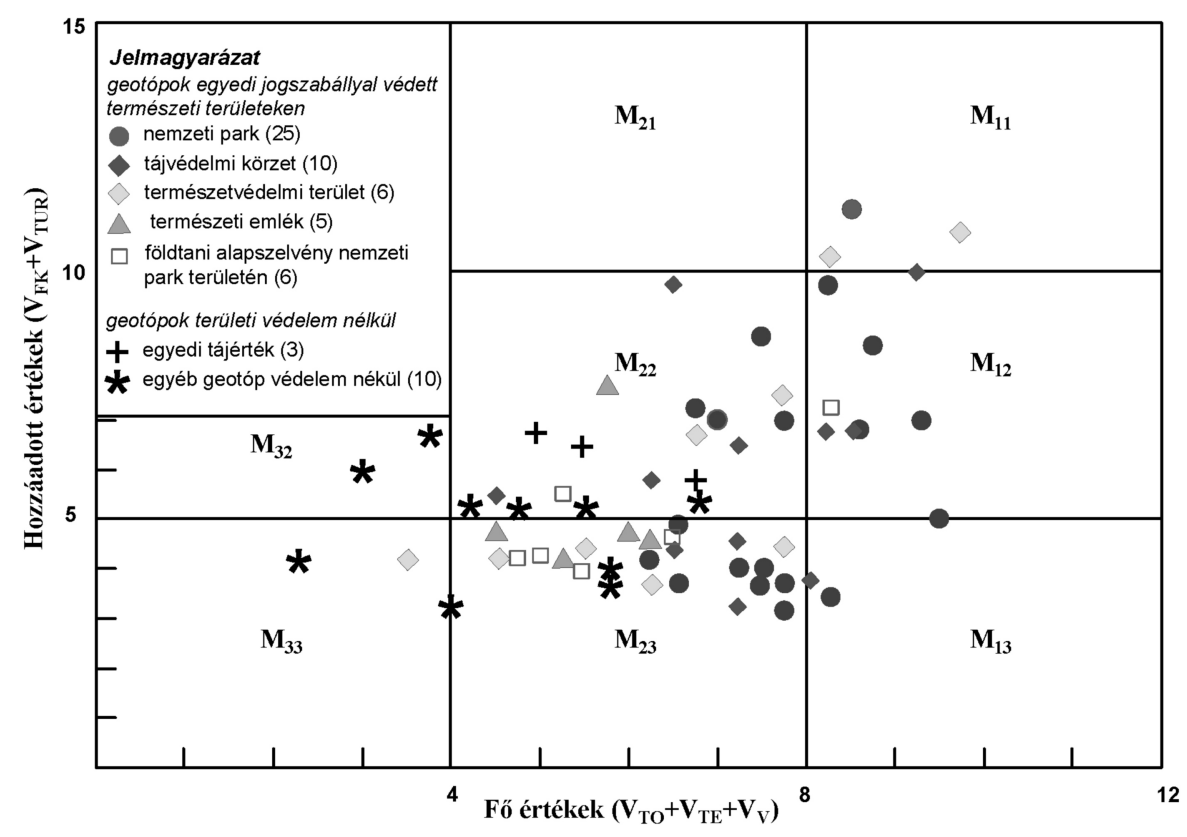

2a ábra. A vizsgált föltudományi értékek elhelyezkedése VuJIČIĆ et al. 2011 minősítő diagramján, a geotópok/ geormorfotópok rendszerezése a védett természeti területek és értékek hazai csoportositását követi

Figure2a. Position of geosites/geomorphosites according to plot of VUJIČĆ et al. 2011, the legend classification is based on the major categories of the domestic nature conservation nomenclature

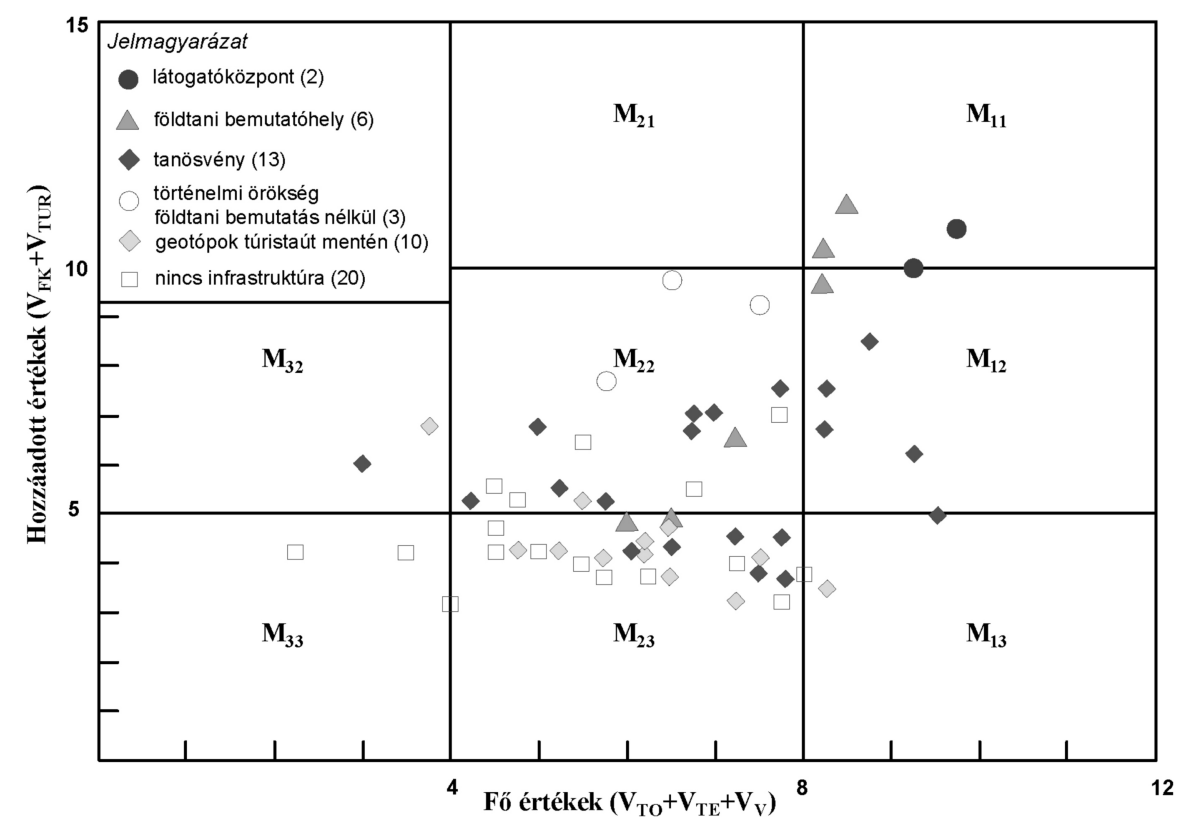

2b ábra. A vizsgált föltudományi értékek elhelyezkedése VuJIČıć et al. 2011 minősitő diagramján, a geotópok/ geormorfotópok rendszerezése a geoturisztikai értékek hazai csoportosítását követi

Figure 2b. Position of geosites/geomorphosites according to plot of VUJIČIĆ et al. 2011, the legend classification and nomenclature is based on the major types of the geotouristical utilization 
tikai indikátorok, de mindenképpen elősegítik a hasznosítást. Ilyenek a közvetlen megközelíthetőség, az úthálózat minősége, infrastrukturális mutatók, további (természeti, kulturális) értékek, vonzáskörzet. A turisztikai indikátorok $\left(\mathrm{V}_{\mathrm{TUR}}\right)$ már ténylegesen a szolgáltatások minőségét, a marketing szerepét, a látogatószámot, vezetett túrák elérhetőségét értékelik. Ez alapján a legmagasabb pontszámokat $\left(\mathrm{V}_{\mathrm{FN}}+\mathrm{V}_{\mathrm{TUR}} \geq 10\right)$ a földtudományi látogatóközponttal rendelkező geomorfotópok (Ság-hegy, Ipolytarnóc, Annabarlang, Lillafüred) értek el. A következô csoportba $\left(\mathrm{V}_{\mathrm{FN}}+\mathrm{V}_{\mathrm{TUR}}=7,5-10\right)$ földtudományi bemutatóhelyek (Kálvária-domb, Tata, Gánt-bauxitbánya, Hegyestủ), természetvédelmi területek (Megyer-hegy - Sárospatak, Kaptárkövek - Szomolya) valamint a kultúrtörténeti értékként ismertebb várak (Visegrád, Sirok, Füzér) helyszínei kerültek. Ettôl kisebb értékekkel rendelkezô geotópok turisztikai szerepét földrajzi elhelyezkedésük jelentôsen befolyásolja. Az UNESCO világörökségi helyszínek geodiverzitás elemei, tanösvények geotópjai (pl. Cserépfalu) a turisztikai infrastruktúra egyéb elemeinek fejlettsége miatt nagyobb pontszámot értek el. A Bükk és a Mátra nehezebben megközelíthetô szurdokvölgyei, karsztformái nagyobb tudományos, tájképi és védelmi pontszámaik ellenére turisztikai szempontból kevésbé frekventáltak.

\section{Geotóp minốsítés II. (BRILHA 2016)}

A minősítési rendszer súlyozott pontértékeivel az objektumok helyzete kissé módosult, árnyaltabbá téve a magyarországi geoturizmus helyzetértékelését. A tudományos érték esetében a 300 fölötti pontszámot 6 geotóp haladta meg (pl. Kálvária-domb, Tata, Ság-hegy, Ipolytarnóc, 3. ábra). A súlyozásnak köszönhetően az objektumok fele a legalacsonyabb pontszámú (100-200) kategóriába került, kicsit kevesebb a középső (200-300) kategóriába tartozó geotópok száma. Az oktatási és turisztikai értéket hasonló indikátorok minősítik ( $V$. táblázat). Az oktatási hasznosításnál külön faktorként jelenik meg a didaktikai potenciál, amely a geotóp és a geodiverzitás oktatási szintekhez kötődő bemutathatóságát értékeli. Az általános iskolai, gimnáziumi tananyaghoz valamint az egyetemi szakspecifikus ismeretanyagot együttesen reprezentáló geotópok kapják a legmagasabb pontszámot (4). Ezen kívül 10 másik indikátor ( $V$. táblázat) súlyozott adataiból számított oktatási potenciál 175-340 pont közötti volt. A legkisebb potenciállal $(<200)$ a Tokaji-borvidék egyedi tájértékeket reprezentáló, kulturális örökséget is bemutató objektumai (támfalak, pincék) rendelkeznek. Problémát jelentenek a nagyon specifikus jelenséget bemutató (Kaszonyi-hegy), a fokozottan védett (Ablakoskő-völgy) és a periférikus, nehezen megközelíthetô objektumok (szurdokvölgyek). Kiemelt oktatási potenciállal $(300<)$ rendelkeznek a nemzeti parkok, geoparkok látogatóközpontjai (Ipolytarnóc), bemutatóhelyei és a jól megközelíthetô és a földtudományi ismeretterjesztés szempontjából is fontos egyéb geotópok (tanösvények).

A turisztikai potenciál, a többé-kevésbé ugyanazon indikátorok súlyozása miatt ( $V$. táblázat) a pontszámokat és a geotópok jellegét tekintve hasonló helyzetképet mutat. A jó infrastrukturális (általános és turisztikai) adottságokkal rendelkező területeken elhelyezkedő, kiemelt geológiai látogatóközpontok, bemutatóhelyek, tanösvény objektumok nagy pontszámot kaptak $(300<)$. Ebbe a csoportba sorolhatók még földtudományi bemutatást nélkülöző, de eróziós vulkáni formákhoz kapcsolódó várak helyszínei (Visegrád, Füzér, Sirok, IV. táblázat). Itt az általános és a turisztikai infrastruktúra fejlettsége ad kiemelt jelentőséget. Ennek hiányában a geotópok (geo)turisztikai potenciálja kifejezetten alacsony $(<250,3$. ábra $)$.

A degradációs veszélyek esetében az objektumok több mint fele kifejezetten alacsony pontszámot kapott $(<200)$, ezek nagy része nemzeti parkok területén elhelyezkedő geotóp. A turisztikai potenciál növekedése a védett területeken is leromlási kockázatot jelent. Nagyobb a degradációs veszély a tényleges jogi védelem nélküli objektumok (pl. egyedi tájértékek, kőbányák) esetében. Összességében a nagy kockázatú geotópok csoportjába $(300<)$ csak egy helyszín került (Kazár), de ott is a természeti folyamatok járulnak hozzá a degradációhoz.

\section{Diszkusszió}

Zsigmond király 1426-ban kelt, közvetve a földtani értékek oltalmát is elősegítő erdővédelmi rendelete után az aktív földtudományi természetvédelemre irányuló erőfeszítések a 20. század elején kezdődtek Magyarországon (Lass 1908, KAÁN 1909, 1931, DÉCHY 1918, id. NosZKY 1931, SZONTAGH 1914). A földtani természetvédelem önálló fogalomként 1954ben jelent meg hazánkban (TASNÁdI KUBACSKA 1954). A VADÁsz Elemér (Természetvédelmi Tanács elnöke), vezetése mellett folytatódó munka eredményeként több mint 100 objektum védetté nyilvánítása történt meg (RAKONCZAY 1986), részben megalapozva a későbbi nemzeti parkok létrehozását. Ehhez képest a geoturizmus, mint a turizmus kifejezetten a földtudományi értékek bemutatásához kötődő, alternatív ága viszonylag fiatal múlttal rendelkezik (DowLING \& Newsome 2006, NewSOME \& Dowling 2010). A geodiverzitás jelentőségének felismerését és értelmezését (SHARPLES 1993, GRAY 2004) a geoturizmus mint alternatív turisztikai ágazat infrastruktúrájának (tanösvények, látogatóközpontok) kiépítése, majd az elsô geoparkok megalapítása követte (GEROLSTEIN \& VULKANEIFEL; FREY 1998, Frey et al. 2006). A geoturizmus fogalma hazánkban is a geoparkok megalapításával került be igazán a köztudatba.

Ezek létrehozása komplex földtudományi természetvédelmi adatbázisok építését kívánja meg (REYNARD et al. 2016, BRILHA 2016), a földtudományi értékek pontos felmérését, a bemutatás és védelem kockázatainak értékelését igényli. Az elmúlt egy évtizedben a nemzetközi módszertan a geotópok kataszterezésétől eljutott a komplex, regionális fejlesztések számára is használható adatbázisok felépítéséhez (Feuillet \& Sourp 2011, Fassoulas 2012, Poiraud et al. 2016). Bár hazánkban is az elmúlt évtizedekben több, a természeti, földtani értékeinket számba vevő összefoglaló munka született (KoPASz 1978, TARDY 1996, KIss 2008, KISS 

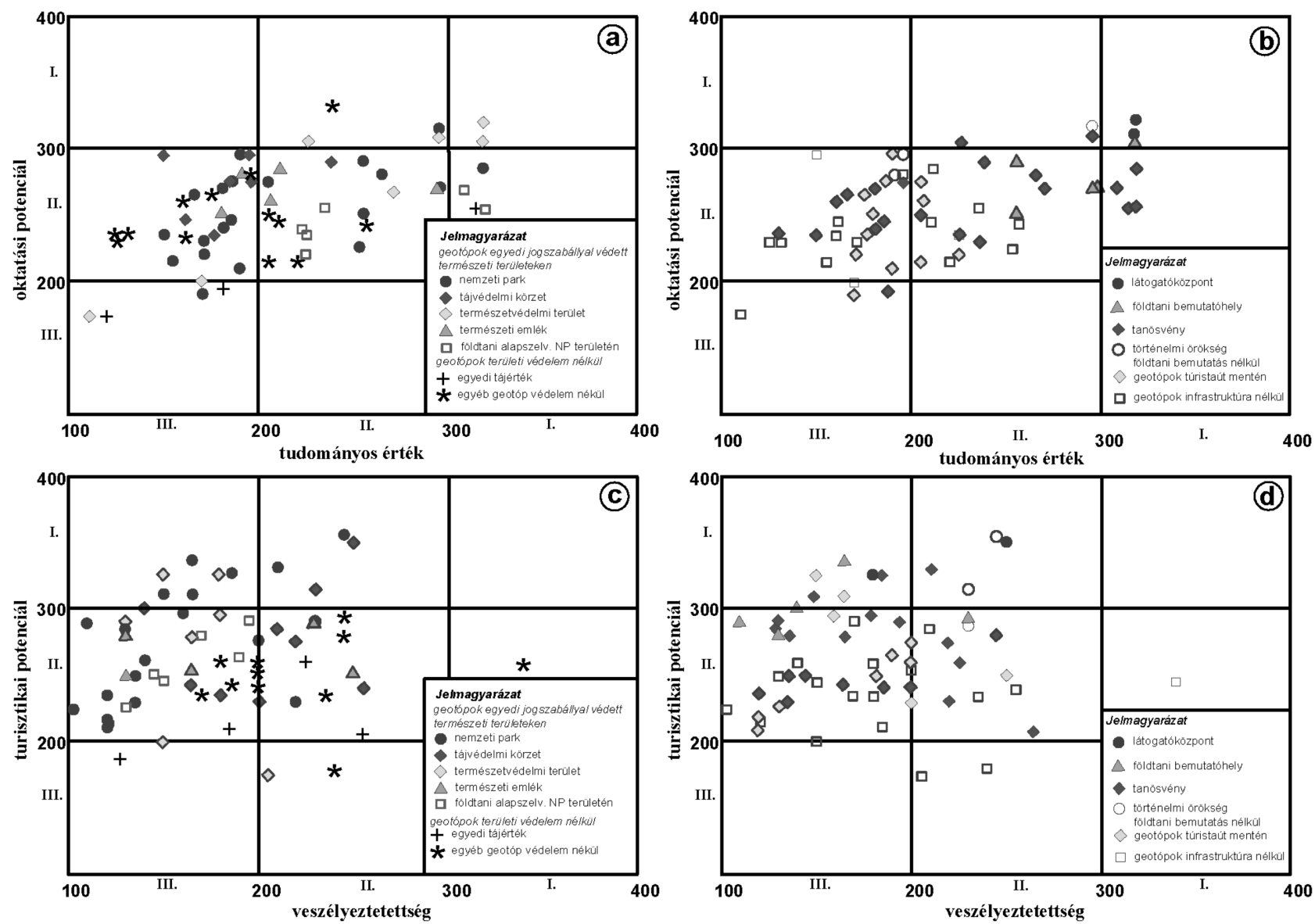

3. ábra. a) A vizsgált geotópok/geomorfotópok tudományos érték/oktatási potenciál diagramja (pontszámok BRILHA 2016 alapján), a geotópok/geormorfotópok rendszerezése a védett természeti területek és értékek hazai csoportosítását követi. b) A vizsgált geotópok/geomorfotópok tudományos érték/oktatási potenciál diagramja (pontszámok BRILHA 2016 alapján) a földtudományi értékek rendszerezése a geoturisztikai hasznosítás legfontosabb típusait követi. c) A vizsgált geotópok/geomorfotópok degradációs kockázat és turisztikai potenciál diagramja (pontszámok BRILHA 2016 alapján), a földtudományi értékek rendszerezése a védett természeti területek és értékek hazai csoportosítását követi. d) A vizsgált geotópok/geomorfotópok degradációs kockázat és turisztikai potenciál diagramja (pontszámok BRILHA 2016 alapján), a földtudományi értékek rendszerezése a geoturisztikai hasznosítás legfontosabb típusait követi

Figure 3. a) Scientific value vs. pedagogic potential plot of geosites/geomorphosites (scores based on BRILHA (2016), the legend classification is based on the major categories of the domestic nature conservation nomenclature. b) Scientific value vs. pedagogic and geotouristic potential plot of the selected geosites/geomorphosites (scores based on BRILHA 2016), the legend classification is based on the major categories of the geotouristic utilization. c) Degradation risks vs. geotouristic potential plot of the selected geosites/geomorphosites (scores based on BRILHA 2016), the legend classification is based on the major categories of the domestic nature conservation nomenclature. d) Degradation risks vs. geotouristic potential plot of the selected geosites/geomorphosites (scores based on BRILHA 2016), the legend classification is based on the major categories of the geotouristic utilization

\& BENKHARD 2007, BUDAI \& GYALOG 2009) a bemutatás, védelem, turizmus szempontjait egységesen értékelő, országos adatbázis megalapozása azonban nem történt meg. Egy ilyen adatbázis létrehozása több fázisra bontható. Az értékfelmérési szakaszban (PEREIRA \& PEREIRA 2005, REYNARD et al. 2016) a szakirodalom áttekintését a potenciális geotópok számbavétele követi (SzEPESI et al. 2017), majd a területi tervezés igényeit figyelembe véve a megfelelô módszertan kiválasztása után ezek számszerú értékelésével alakul ki a végső területi lista. A munka második szakaszát a turisztikai fejlesztés fázisa jelenti, amely már a konkrét koncepciók megalapozását szolgálja ki. Ez a földtudományok, a természetvédelem és regionális fejlesztési szervezetek szoros együttmúködését kívánja meg. A földtudományi oldalról idáig megjelent kötetek, tanulmányok a létrehozott adatbázisok a turisztikai szektor számára azonban mindeddig nem tudtak kellően hatékony információszolgáltatást biztosítani.
Ennek tükrében a hazai geoturisztikai potenciál értékeléséhez igyekeztünk mind a geotópok jellegét tekintve (földtudományi értékek, alapszelvények, egyedi tájértékek) mind a természetvédelemi oltalom fokát nézve reprezentatív adatbázist összeállítani (1. ábra, IV. táblázat). A területi eloszlást és geoturisztikai potenciált tekintve fontos volt, hogy a Globális Geopark Hálózathoz tartozó két geoparkunk (Bakony-Balaton és Novohrad-Nógrád Geopark) több geotóppal képviselve legyen. Ezt egészítik ki hazánk reprezentatív földtani bemutatóhelyei (pl. Kemenes Vulkánpark, Kálvária-domb, Tata) és geoturisztikai fejlesztések szempontjából potenciális területek és geotópok (Mátra, Bükk, Tokaji-hegység).

A hazai és nemzetközi geotóp minôsítés (I., IIa és $b$ táblázat) szempontrendszerének fejlődését áttekintve két, a különböző értékkategóriákat (tudományos, esztétikai, védelem, oktatás, turisztikai potenciál) komplexen értékelő módszert (VuJIČıć et al. 2011, BRILHA 2016) választottunk a 
geotópok helyzetértékeléséhez. Míg az elsôt már több mintaterületen alkalmazták (VIŠNIĆ et al 2016, MoUFTI et al. 2013, ÉsıK et al. 2015, SzEPESI et al. 2017), a másodiknak ez az első esettanulmánya.

\section{A geoturisztikai infrastruktúra állapota}

Magyarországon a földtani örökség turisztikai hasznosítása barlangok látogathatóvá tételével (Aggtelek, Budapest, Lillafüred, Tapolca) a védett természeti területeken kialakított bemutatóhelyek (Tihany, Tata, Sümeg, Ipolytarnóc, Hegyestú), tanösvények létrehozásával kezdődött (pl. TARDY \& ORAVECZ 1990, Kiss et al. 1999, MARTONNÉ et al. 2003). Ehhez társult az ex-situ bemutatást lehetôvé tevô földtudományi gyújtemények anyagának összeállítása (Magyar Természettudományi Múzeum, Herman Ottó Múzeum, Telkibánya, Rudabánya stb, KECSKEMÉTI \& PAPP 1994). Bár a nemzeti parki igazgatóságok feladatai közé az élettelen természeti értékek kezelése is hozzátartozik, ez a természetvédelem túlzottan ökológiai szemléletú megközelítése miatt gyakran háttérbe szorult. Ebben a viszonyrendszerben előrelépést jelentett, a geoturizmus egyre hangsúlyosabb hazai megjelenését igazolva, az első geoparkok megalapítása (2010, 2012), amelyek a Globális és Európai Geopark Hálózat tagjai is egyben (www.globalgeopark.org). További kiemelt földtani bemutatóhelyeink a tatai Káváriadomb, a Kemenes Vulkánpark (2013). Az ezekhez kapcsolódó infrastrukturális fejlesztések megteremtették az alapot ahhoz, hogy a területükön elhelyezkedő geotópok bemutatása a legkorszerúbb szemléltetési lehetôségekkel és képzett szakemberállománnyal valósulhasson meg. Ezek a kapcsolódó földtani kutatómunka eredményeképpen (NÉMETH et al. 2001, JANKOVICS et al. 2015) tudományos szempontból is kiemelt szerepet töltenek be. Mindkét geotóp értékelési módszer kiemeli vezetô szerepüket (2. ábra, $a, b, 3$. ábra), ezek a hazai geoturizmus legfontosabb célterületei (Ipolytarnóc, Sághegy). A személyi állomány összetétele lehetôvé teszi a látogatóközpontok magas színvonalú bemutatását, valamint vezetett geotúrák folyamatos szervezését. Ehhez járul hozzá a Bakony-Balaton Geopark nyílt geotúra vezetố tanfolyama, amely 2016-ig a geopark 9 területi egységét lefedve bővíti a geotúra-vezetők körét (www.geo-park.hu).

Nagy pontszámokat értek el a városi központok, turisztikai célterületek közelében elhelyezkedô földtani bemutatóhelyek (Tata, Kálvária domb), tanösvények (Megyerhegy, Sárospatak). Ide sorolhatók azok a történelmi emlékhelyek, várak helyszínei, amelyek nem jöhettek volna létre a formákat kialakító eróziós folyamatok nélkül, azonban mégsem nyújtanak földtudományi ismeretterjesztést (Visegrád, Sirok, Füzér). További geoparkok létrehozása során (Bükk, Tokaji-hegység) ezek lehetnek a további geoturisztikai fejlesztések célterületei, ahol a geopark eszközrendszere ad alapot a geoturisztikai potenciál kiemeléséhez.

A kis turisztikai célérték számok $(\mathrm{GAM}<5$, BRILHA: <250) mögött egyrészt infrastrukturális problémák húzódnak, mint a gazdaságilag elmaradott terület, periférikus elhelyezkedés (Kaszonyi-hegy), problémás megközelítés (szurdokvölgyek). Másrészt a természetvédelmi kezelés jellege jelent problémát, amely sok tudományos szempontból jól feldolgozott geotóp esetében gátolja a hasznosítást és a bemutatást (Bükk-fennsík).

\section{Bemutathatóság, oktatási potenciál}

A bemutathatóságot a két minősítési rendszer eltérően értelmezi. VuJičıć et al. 2011 a tudományos/oktatási értékek indikátoraként használja, a fô értékek részösszesítésében $\left(\mathrm{V}_{\mathrm{TO}}+\mathrm{V}_{\mathrm{TE}}+\mathrm{V}_{\mathrm{V}}\right)$ nem kapott önálló alkategóriát. Itt a legmagasabb értéket a látogatók számára könnyen értelmezhetô, az adott természeti folyamatra/képződményre jellemző geotópok kapják. Míg a kevésbé típusos, nehezebben bemutatható, értelmezhetô folyamatok kisebb értékszámmal szerepelnek. BRILHA (2016) rendszere egyértelmúen különválasztotta a turisztikai és oktatáshoz kötött potenciált. A turisztikai bemutathatóság szakmai értelmezése az előzőhez hasonló, azaz földtudományok területéról mennyire kell szakmai ismeretekkel rendelkezni a látogatónak az adott jelenség értelmezéshez (könnyebb értelmezhetőség = magasabb pontérték). Az oktatás esetében döntő, hogy a tanulók az adott kőzettel, folyamattal, formával az oktatás mely szintjén (általános, középiskola) találkoznak. Ez alapján az általános iskola nemzeti kerettanterveiben (kerettanterv. ofi.hu) megjelenő általános folyamatokat (pl. vulkanizmus, karsztosodás) reprezentáló, sok esetben kisebb tudományos értékú (pl. forrás) geotópok is érhettek el nagyobb pontszámot. Ezzel szemben az egyetemek specifikus szakterületi ismeretanyagában (pl. vulkáni tufák összesülése, karbonátplatform képződése) megjelenő geotópok potenciálja kisebb.

A két mutató végső pontszámát több indikátorral együtt (pl. gazdasági fejlettség) súlyozva kapta (IV. táblázat, 3 . ábra), amely jelentősen árnyalja a képet. A geoparkok területén elhelyezkedő geotópok turisztikai és oktatási potenciálját nagy minôsítő értékszámaik $(250<, 3$. ábra $)$ is igazolják. A földtani alapszelvények szakmaspecifikus ismeretanyaga azonban több esetben kis pontszámokat eredményezett. Hasonló a helyzet a földtudományi vonatkozású egyedi tájértékek esetében is.

A geotópok ismeretanyagában rejlő oktatási potenciál mellett fontos, hogy a 21. században milyen módon tudjuk mindezt a fiatalabb generációk számára átadni. Az elmúlt évtizedek statikus, múzeumi kiállításai nem tudnak megfelelő érdeklődést kiváltani és a figyelmet tartósan fenntartani. A geopark (vulkánpark) látogatóközpontok már olyan technológiákat is alkalmaznak (interaktív animációk, szimulátor, filmvetítés, 3D szemléltetés), amellyel a gyerekek aktív részesei lehetnek a megismerésnek. A digitális szemléltetés, animációk lehetőségeit a terepi bemutatás (tanösvények) során is ki lehet használni (pl. RAPPRICH 2017). Bár a mobiltelefon lefedettség csak, mint biztonsági indikátor szerepelt (BRILHA 2016), de segítségével QR kódon keresztül elérhetővé lehet tenni digitális tartalmakat, amely a terepen elhelyezett információs táblák anyagát is részben helyettesítheti, illetve azt kiegészíti.

A földtudományi értékek aktív ismeretszerzésen keresz- 
tül történő átadása szintén jelentős érdeklődést válthat ki. Jól mutatják ezt az immár egy évtizedes múltra visszatekintő Geotóp nap, valamint a Mesélő kövek (meselo-kovek.hu) vezetett túrái. A német mintára (LOOK \& FELDMANN 2006, LAGALLY et al. 2015) 2008-ban Cserépfalun, a LESS Nándor emléktúrák kísérô rendezvényeként életre hívott Geotóp nap kezdeményezés (SÜTő et al. 2011) a Magyarhoni Földtani Társulat ProGeo Földtudományi Természetvédelmi Szakosztályának égisze alatt vált országos méretú programmá. 2016-ban vezetett túrákkal 19 helyszínen zajlottak a programok. Cserépfalun a geotópoknál zajló kiegészítő előadások, terepi vulkánmodell-építés, a horzsakőúsztatás sikere mutatja, hogyan lehet a földtudományi ismereteket közelebb vinni az arra fogékony közönséghez. Ezekkel a programokkal az önállóan viszonylag kis pontszámokat elért geotópok (Ördögcsúszda, Hór-völgyi-kőfejtő alapszelvénye) ismertsége, turisztikai jelentősége növelhető.

\section{Védelem és turizmus konfliktusai}

A feltárások veszélyeztetettségének átfogó értékelése BRILHA (2016) rendszerében jelent meg. A vizsgált geotópok jelentôs része védett természeti területen helyezkedik el (nemzeti park, tájvédelmi körzet, természetvédelmi terület) vagy ex lege (barlang, forrás) védelem alatt áll. Ennek megfelelően az antropogén eredetú veszélyek kockázata, ahogy ez a kapott pontszámok alapján is látszik (3. ábra, IV. táblázat), a geotópok mintegy 65 százalékénál meglehetősen kicsi és a többi objektum esetében is csak közepes. A turistautak környezetének veszélyeztetettsége még nemzeti parkok területén sem igényel az általános előírásokon (elhagyási tilalom) túli speciális intézkedéseket. A kiemelt aktív turisztikai rendezvények (teljesítménytúrák) pedig létszámkorlát mellett szervezhetôk. A legveszélyeztetettebb kazári riolittufa-felszín helyzete kettős. Létrejöttét antropogén hatásoknak köszönheti, azonban ma már természetes folyamatok okozzák további erózióját, amely a formakincs további fejlődéséhez járul hozzá.

Természetvédelem és geoturizmus sajátos metszéspontjaként jelentenek problémát az intenzív ásvány és ősmaradványgyưjitéssel veszélyeztetetett geotópok (pl. BALÁzsı 2013). Ezek esetében egyes ásványfajok teljesen lefejtésre kerültek, ahogyan ezt a Tokaji-hegység több lelőhelye is bizonyítja (gránát riolitban, Kis-Sertés-hegy). Bár az 1996. évi LIII. törvény megfogalmazása szerint védetté kell nyilvánítani (egyebek mellett) az arra érdemes ásványokat, ősmaradványokat, és ezek jelentős lelőhelyeit, a feladat elvégzésére sokáig megoldatlan maradt. Az elmúlt években a Földmúvelésügyi Minisztérium Nemzeti Parki Főosztálya és a Magyar- honi Földtani Társulat a Beszámoló az ásványok, ósmaradványok, és lelóhelyeik védetté nyilvánításáról szóló jogszabály tervezetének elókészitéséról címmel kérte a szakmai közvéleményt a témával kapcsolatos állásfoglalásra. Ennek eredményeként született meg a 55/2015. FM rendelet, amely jogi védelem alá helyezve, részletes kezelési tervben határozta meg a tudományos kutatás és gyújtés feltételeit. Területileg illetékes nemzeti parki igazgatóságok megkezdték az érintett geotópok kataszterezését, amelybe ásványgyújtéssel érintett objektumok is bekerültek (Kis-Sertés-hegy Gönc, Királyhegy Telkibánya, Zempléni Tájvédelmi Körzet). Véleményünk szerint azonban az ,amatốr” gyújtők által begyújtött anyagok, a jogszabály szerint közgyújteményi elhelyezést igénylő példányok tudomány számára való elérhetősége, dokumentálhatósága sokáig megoldatlan kérdés marad.

\section{Záró gondolatok}

A földtudományi értékek és a geodiverzitás fontosságának felismerése hazánkban is megtörtént. Ezt az eredményesen múködő geoparkok, a bemutatóhelyek számának növekedése, a geotúra-vezetôk képzésének beindulása a kapcsolódó geoturisztikai, ismeretterjesztő rendezvények látogatottságának folyamatos emelkedése igazolja. A Magyar Geopark Bizottság ülésén felmerült a lehetősége, hogy a két hazai UNESCO Globális Geopark (Bakony-Balaton, Novohrad-Nógrád) mellett további, akár nemzeti szinten múködő szervezetek jöjjenek létre. Az ezeket megalapozó fejlesztési tervek a geotópok részletes felmérésén kell, hogy alapuljanak. Jelenleg erre nincs elfogadott dokumentációs és értékelési módszer, amely a bemutathatóság, védelem, turisztikai potenciál szempontjait komplexen értékelné. Tanulmányunk ehhez is igyekszik módszertani kiindulási alapot szolgáltatni.

\section{Köszönetnyilvánítás}

A tanulmány elkészítését az OTKA K 101787 pályázata támogatta. Emellett szeretnénk köszönetet mondani a tanulmány bírálóinak akiknek kritikai észrevételei nagyban hozzájárultak a kézirat végsô változatának elkészítéséhez. Köszönjük VINCZE Péternek a hazai természetvédelem, KORBÉLY Barnabásnak a geoturizmus fogalomrendszerének szakszerû használatára tett megjegyzéseit. A földtani értékminősítési rendszerek összehasonlító vizsgálata a Tokajihegységi mintaterületen ÉsıK Éva Zsuzsanna PhD kutatómunkájának a része.

\section{Irodalom — References}

AlberT G. \& Csillag G. 2011: A Káli-medence geológiai látványosságai. — http://www.elgi.hu/hu/node/417.

BALÁzSI T. 2013: Az ásványgyújtés természeti környezetre gyakorolt hatásainak jellemzése Telkibánya környezetében. — Tudományos Diákkör Dolgozat, Nyíregyházi Fóiskola, Turizmus és Földrajztudományi Intézet 70 p. 
Barettino, D., Vallejo, M. \& Gallego, E. (eds) 1999: Towards the Balanced Management and Conservation of the Geological Heritage in the New Millenium. - III. International Symposium ProGEO on the Conservation of the Geological Heritage. Madrid, Sociedad Geologica de Espana, p. 204.

BEDŐ G., CsEPREGI I. \& SzuRKos G. 2006: A földtani természetvédelem kialakulásának és hazai történetének rövid áttekintése a természet védelméról szóló törvény elfogadásáig. — ACTA GGM Debrecina Geology, Geomorphology, Physical Geography Series 1, 107-121.

Brum da Silveira, A., Prada, S., Brilha, J. \& Ferreira. M. 2015: Inventory of geological heritage in volcanic islands: methods and results obtained in Madeira Island. - $2^{\text {nd }}$ Volcandpark Conference, Lanzarote Abstract Book 5-6.

BudAI T. \& GyAlOG L. (szerk.) 2009: Magyarország Földtani atlasza országjáróknak. — Magyar Állami Földtani Intézet 248 p.

BRILHA, J. 2002: Geoconservation and protected areas. — Environmental Conservation 29/3, 273-276. https://doi.org/10.1017/ s0376892902000188

BRILHA, J. B. 2011: Geoconservation: promoting the sustainable use of geodiversity for science, education and geotourism. — The International Workshop "Patri-moine géologique et développement durable de la région de Rabat Salé Zemmours Zaers". Résumés des conférences, 22-23.

BRILHA, J. 2016: Inventory and quantitative assessment of geosites and geodiversity sites: a review. — Geoheritage 8, 116. https://doi.org/ 10.1007/s12371-014-0139-3

Brocx, M. \& SEmEnIUK, V. 2007: Geoheritage and geoconservation - history, definition, scope and scale. — Journal of the Royal Society of Western Australia 90, 53-87.

Bruschi, V. M. \& CENDrero, A. 2005: Geosite Evaluation; Can we measure intangible values? - Il Quaternario 8/1, $293-306$.

Bruschi, V. M., Cendrero, A. \& Albertos, J. A. C. 2011: A statistical approach to the validation and optimisation of geoheritage assessment procedures. — Geoheritage 3/3, 131-149. https://doi.org/10.1007/s12371-011-0038-9

Burek, C. V. \& Prosser, C. D. 2008: The history of geoconservation: an introduction. - The History of Geoconservation. The Geological Society, London, Special Publications 300, 1-7. https://doi.org/10.1144/sp300.1

Carcavilla, L,. Lopez Martinez, J. \& Durn Valsero JJ. 2007: Patrimonio Geologico y Geodiversidad: investigacion, conservacion, gestion y relacion con los espacios naturales protegidos. - Instituto Geologico y Minero de Espana, $360 \mathrm{p}$.

DÉCHY M. 1918: A természet védelme és a nemzeti parkok. — Term. Tud. Közlöny 546. klny, 1-21.

DowLING, R. K. 2011: Geotourism's Global Growth. — Geoheritage 3/1, 1-13. https://doi.org/10.1007/s12371-010-0024-7

DowLING R. K. 2016 The 'ABC' Approach for Successful Geotourism Interpretation http://www.leisuresolutions.com.au/wp-content/ uploads/2015/02/Geotourisms-Interpretation-Dowling.pdf

Dowling, R. K. \& Newsome, D. 2006: Geotourism. - Elsevier, Oxford, 289 p.

ERHARTí́, B. 2010: Geomorphosite assessment. — Acta Geographica Slovenica 50/2, 295-319. https://doi.org/10.3986/ags50206

ÉsIK, Z., SZEPESI, J. \& RózSA, P. 2015: Geosite inventory and assessment of Tokaj Wine Region, Historic Cultural Landscape, Hungary. $-2^{\text {nd }}$ Volcandpark Conference, Lanzarote Abstract Book, 6-7.

Fassoulas, C., Mouriki, D., Dimitrou-Nikolakis, P. \& Iliopoulos, G. 2012: Quantitative assessment of geotopes as an effective tool for geoheritage management. — Geoheritage 4, 177-193. https://doi.org/10.1007/s12371-011-0046-9

FEuilliet, T. \& SourP, E. 2011: Geomorphological heritage of the Pyrenees National Park (France): Assessment, clustering and promotion of geomorphosites. — Geoheritage 3, 151-162. https://doi.org/10.1007/s12371-010-0020-y

FrEY, M. L. 1998: Geologie - Geo-Tourismus - Umweltbildung: Themen und Tätigkeitsbereiche im Spannungsfeld Ökonomie und Nachhaltige Entwicklung. - Terra Nostra, Schriften der Alfred-Wegener Stiftung 98/3, V85.

Frey, M. L., SchäFer, K., Büchel, G. \& PAT, M. 2006: Geoparks - a regional, European and global policy. - Dowling, R. K., Newsome, D. (eds): Geotourism. Elsevier, 95-118. https://doi.org/10.1016/b978-0-7506-6215-4.50014-2

Gellai M. \& BAROSS G. 1995: Fejezetek és gondolatok a földtani természetvédelem kialakulásáról, tartalmáról (és mai helyzetéről), avagy a hazai földtani természetvédelem 569 éve. — Földtani Közlöny 125/1-2, 149-165.

GRANDGIRARD, V. 1999: L'evaluation des geotopes. — Geologia Insubrica 4, 59-66.

GRAY, J. M. 2004: Geodiversity: Valuing and conserving abiotic nature. — Chichester: Wiley, 448 p.

GrAY, J. M. 2008: Geodiversity: developing the paradigm. — Proceedings of the Geologists'Association 119, 287-298. https://doi.org/ 10.1016/s0016-7878(08)80307-0

Gsa Position Statement Draft 2011: Geoheritage. - GSA Today 21/4, 56-58.

Gyalog L., Maros Gy. \& PeliKán P (szerk.) 2017: Budapest geokalauz. — Magyar Földtani és Geofizikai Intézet, Budapest 314 p.

Harangi, Sz., Németh, K., Korbély, B., Szepesi, J., Szarvas, I., Lukács, R. \& Soós, I. 2015: The Pannonian Volcano Route: a plan to connect volcanic heritage sites across Hungary. — 2 $2^{\text {nd }}$ Volcandpark Conference, Lanzarote Abstract Book 40-41.

HAAS J., \& JÁMBOR Á. 1983: Az Országos Alapszelvény Program végrehajtásának helyzete és eredményei. — Magyar Állami Földtani Intézet évi jelentése az 1981. évról, 27-34.

HerčKo, P., Domaracké, L., Ambroš, P. 2014: Mining Bethlehem at Banská Štiavnica—example of mining heritage in Slovakia. —-Acta Geoturistica 5/2, 64-68

Hose, T. A. 2008: Towards a history of geotourism: definitions, antecedents and the future. — In: BuREK, C. V. \& PROSSER, C. D. (eds): The History of Geoconservation: an introduction. London, Geological Society 37-61. https://doi.org/10.1144/sp300.5

Jankovics, M. É., Harangi, Sz., Németh, K., Kiss, B. \& Ntaflos, T. A. 2015: Complex magmatic system beneath the Kissomlyó monogenetic volcano (western Pannonian Basin): evidence from mineral textures, zoning and chemistry. — Journal of Volcanology and Geothermal Research 301/15, 38-55. https://doi.org/10.1016/j.jvolgeores.2015.04.010

KAÁN K. 1909: A természeti értékek fenntartása. — A Magyar Királyi Földmúvelésügyi Miniszter kiadványai, Budapest, 56 p.

KAÁN K. 1931: Természetvédelem és a természeti emlékek. — Révai Kiadó, Budapest, 312 p.

KeCSKEMÉTI T. \& PAPP G. ed. 1994: Földünk hazai kincsesházai. — Studia natúralia 4, Magyar Természettudományi Múzeum, Budapest 4-32. 
KIss G. 1999: Talajok és morfológiai formák természetvédelmi értékének meghatározása Tokaj-Zempléni-hegyvidéki példákon. —PhD értekezés. Kossuth Lajos Tudományegyetem, Debrecen 150 p.

KIsS G. 2001: Földtudományi értékek természetvédelmi szempontú kataszteri nyilvántartása. — In: DoRMÁNY G., KovÁcs F., PÉTI M. \& RAKONCZAi J. (szerk.): A földrajz eredményei az új évezred közepén. Magyar Földrajzi Konferencia elöadásai 12 p.

KIss G. 2005a: A földtudományi természetvédelmi felmérés értékelés-módszertani vonatkozásai és tapasztalatai. — Tájökológiai Lapok 3/2, 201-210.

KISS G. 2005b: Földtudományi Természetvédelmi Felmérés - a Földtudományi Értékek Országos Katasztere összeállítása. — In: DoвOS A. \& ILYÉs Z. (szerk.): Földtani és felszínalaktani értékek védelme. 35-46.

KIss G. 2008: Földtudományi képződmények természetvédelmi értékelésének módszertana: a ritkasági-gyakorisági érték, a veszélyeztetettségi érték és az oktatási-nevelési érték meghatározása, valamint az értékkataszterezés egységes szempontrendszerének kidolgozása. — T 043789 nyilvántartási számú OTKA témapályázat kutatási zárójelentés 88 p.

KIss G. \& BABus F. 2011: Magyar táj — magyar örökség. A tájkarakter védelmétôl az egyedi tájértékek megôrzéséig. — Budapest, Vidékfejlesztési Minisztérium Környezet- és Természetvédelmi Helyettes Államtitkársága, 28 p.

KISS G. \& BENKHARD B. 2007: Kö kövön... marad Útikalauz látványos földtani, felszínalaktani és víztani objektumok megismeréséhez. — Környezetvédelmi és Vízügyi Minisztérium 216 p.

KIsS G., HaVASSY A. \& BARKó O. 1999: Komlóskai „Telér” tanösvény. — Kirándulásvezető füzet. Komlóskai Önkormányzat 38 p.

KIss G. \& HoRvÁTH G. 2003: A természetvédelmi értékelések kritériumainak értelmezése és földtudományi értékekre való alkalmazhatósága. — Földrajzi Közlemények. 137 (51) 1-4, 63-76.

Kiss G., Szepesi J., Oláh T., Barkó O., SzéPvölgyi Á., Kalenyák E., Proksa K. \& Tomor T. 2000: „Kormos Bába” Tanösvény FüzérPusztafalu-Füzérkajata-Füzérradvány. - Kirándulásvezető füzet, Pusztafalu, Füzérkajata, Füzérradvány és Füzér község önkormányzata

Kiss G., Tóth Sz., SiKabonyi M. \& FARKAS R. 2011: Mindennapi kisemlékeink megôrzéséért. Útmutató az egyedi tájértékek kataszterezéséhez. - Vidékfejlesztési Minisztérium Környezet- és Természetvédelmi Helyettes Államtitkársága 40 p.

Kopasz M. szerk. 1978: Védett természeti értékeink. — Mezőgazdasági Kiadó, Budapest 395 p.

KoZÁK M., PÜSPÖKI Z. \& MAjoros Zs. 1998: Földtani értékek védelme. — Acta Geogr. ac. Geol. et Meteor. Debrecina $35,327339$.

Kubalikova, L 2013: Geomorphosite assessment for geotourism purposes. — Czech Journal of Tourism 2, 80-104, https://doi.org/ 10.2478/cjot-2013-0005

Lagally, U., Loth, R. \& Schindelmann, C. 2015: The "Day of Geosites" in Germany - a Successful Promotion Tool for Earth Sciences. — Geoheritage 7/2, 195-204. https://doi.org/10.1007/s12371-014-0127-7

LASS S. 1908: „Nemzeti Parkok” — Magyarország természeti kincseinek megőrzése. — Pesti Hírlap, január 5.

LÓCZY, D. (ed.) 2015: Landscapes and Landforms of Hungary. — Springer International Publishing 294 p. https://doi.org/10.1007/9783-319-08997-3

Look, E.-R. \& Feldmann, L. 2006: Faszination Geologie. Die bedeutendsten Geotope Deutschlands. — Schweizerbart'sche Verlagsbuchhandlung, 179. p.

MartonNÉ ERdôs K., Kiss G., SzEPEsi J. \& Dobos A. 2003: A cserépfalui Ördögtorony tanösvény. Kirándulásvezető füzet. — Holocén Természetvédelmi Egyesület 45 p.

McAdAm A. D. \& Clarkson, E. N. K. 1986: Lothian Geology. An excursion guide. — Edinburgh Geological Society, Scottish Academic Press, Edinburgh.

Mouft, M. R., NÉMETH, K., El-MASRI, N. \& QADDAH, A. 2013: Geoheritage values of one of the largest maar craters in the Arabian Peninsula: the Al Wahbah Crater and other volcanoes (Harrat Kishb, Saudi Arabia). — Cent. Eur. J. Geosci. 5/2, $254-271$. https://doi.org/10.2478/s13533-012-0125-8

Mûszaki Szabvány Az egyedi tájértékek kataszterezéséhez. MSZ 20381:1999. — Magyar Szabványügyi testület, 1999.

Newsome, D. \& Dowling, R. K. (eds) 2010: Geotourism: The tourism of Geology and Landscape. — Oxford, Goodfellow Publishers Ltd. 260 p.

NÉMETH, K., MARTin, U., HARAngi, Sz. 2001: Miocene phreatomagmatic volcanism at Tihany (Pannonian Basin, Hungary). — Journal of Volcanology and Geothermal Research 111/1-4, 111-135. https://doi.org/10.1016/s0377-0273(01)00223-2

NosZKY J. 1931: Természetvédelmi feladataink a geológia terén. — Földtani Közlöny 61, 103-108.

O'Halloran, D., Green, C., Harley, M., Stanley, M. \& Knill, J. (eds) 1994: Geological and Landscape Conservation. — Proceedings of the Malvern International Conference 1993, London: The Geological Society, 530 p.

PANIZZA, M. 2001: Geomorphosites: concepts, methods and example of geomorphological survey. — Chinese Science Bulletin, 46, 4-6. https://doi.org/10.1007/bf03187227

PAnizZA, M. \& Piacente, S. 2005: Geomorphosites: A bridge between scientific research, cultural integration and artistic suggestion. Il Quaternario 18/1,3-10.

Pereira, P. \& Pereira, D. I. 2010: Methodological guidelines for geomorphosite assessment. - Géomorphologie: Relief, Processus, Environment 2, 215-222. https://doi.org/10.4000/geomorphologie.7942

Pelfini, M. \& Bollati, I. 2014: Landforms and geomorphosites ongoing changes: Concepts and implications for geoheritage promotion. —Quaestiones Geographicae 33/1, Bogucki Wydawnictwo Naukowe, Poznań, 131-143. https://doi.org/10.2478/quageo-2014-0009

Poiraud, A., Chevalier, M., Claeyssen B., Biron, P. \& Joly B. 2016: From geoheritage inventory to territorial planning tool in the Vercors massif (French Alps): Contribution of statistical and expert cross approaches. - Applied Geography 71, 69-82.

PRALONG, J. P. 2005: A method for assessing tourist potential and use of geomorphological sites. — Geomorphologie: Relief, Processus, Environnement 1/3, 189-196. https://doi.org/10.4000/geomorphologie.350

Pralong, J. P. \& ReYnARD, E. 2005: A proposal for a classification of geomorphological sites depending on their tourist value. $-I l$ Quaternario 18/1, 315-321. 
PROGEO 2011: Conserving our shared geoheritage a protocol on geoconservation principles, sustainable site use, management, fieldwork, fossil and mineral collecting. - ProGeo, Uppsala. $10 \mathrm{p}$.

RAKONCZAY Z. 1986: Vadász Elemér és a magyar természetvédelem. — Földtani Közlöny 116/1-2, 19-21.

RAPPRICH, V., Lisec, M., Fiferna, P., ZÁvAdA, P. 2017: Application of modern technologies in popularization of the Czech volcanic geoheritage. - Geoheritage 9, p. 413. https://doi.org/10.1007/S12371-016-0208-X

ReYnard, E. 2004: Geosite. - In: Goudie, A. S. (ed.) 2004: Encyclopedia of Geomorphology. Routledge Ltd. 440 p.

REYNARD, E. \& CoRATZA, P. 2013: Scientific research on geomorphosites. A review of the activities of the IAG working group on geomorphosites over the last twelve years. — Geogr. Fis. Dinam. Quat. 36, 159-168.

Reynard, E., Fontana, G., Kozlik, L. \& Scapozza, C. 2007: A method for assessing "scientific" and "additional values" of geomorphosites. — Geographica Helvetica Jg. 62/3, 148-158. https://doi.org/10.5194/gh-62-148-2007

Reynard, E., Coratza, P. \& Regolini-Bissig, G. 2009: Geomorphosites. - Friedrich Pfeil München 240 p.

Reynard, E., Perret, A., Bussard, J., Grangier, L. \& Martin, S. 2016: Integrated approach fro the inventory and management of geomorphological heritage at regional scale. — Geoheritage 8/1, 43-60. https://doi.org/10.1007/s12371-015-0153-0

REYNOLDS, J. 2001: Notes to accompany RIGS recording, assessment and designation and notification sheets. - In: Notes on the UKRIGS Conference 2001. http://wiki.geoconservationuk.org.uk/images/8/8d/Assessinfo.pdf

RYBAR, P. 2010: Assessment of attractiveness (value) of geotouristic objects. — Acta Geotouristica 1/2, 13-21.

Serrano, E. \& GonZalez-Trueba, J. J. 2005: Assessment of geomorphosites in natural protected areas: the Pico de Europa National Park (Spain). — Géomorphologie: Relief, Processus, Environnement 3, 197-208.

SHARPLES, C. 1993: A Methodology for the Identification of Significant Landforms and Geological Sites for Geoconservation Purposes. - Forestry Commission of Tasmania $31 \mathrm{p}$.

SHARPLES, C. 2002: Concepts and principles of geoconservation. — Tasmanian Parks \& Wildlife Service website.

ŠTRBA L. 2015: Identification and evaluation of geosites along existing tourist trail as a primary step of geotourism development: case study from the Spiš Region (Slovakia). — GeoJournal of Tourism and Geosites 16/2, 126-140.

Sütő, L., McIntosh, R. W., Hevesi, A. \& Veress, M. 2015: Bükk Plateau: A Karst Landscape. — In: Lóczy, D. (ed.): Landscapes \& Landforms of Hungary. Springer 189-199.

SÜTŐ, L., SzEPESI, J., NovÁK, T. \& DÁVID, L. 2011: Touristic hiking programs as a possibility of involving the public into earth scientific education. - Acta Geoturistica 2/1, 23-28.

SZABÓ J. \& SÜTŐ L. 2005: Az egyedi tájérték kataszterezési program tapasztalatai a Cserehát példáján. — In: DoBos A. \& ILYÉs Z. (szerk.): Földtani és felszínalaktani értékek védelme. 81-101.

SZEPESI J. \& ÉsiK Zs. 2000: Védendő vulkanológiai szelvények a tokaji Nagy-hegy környezetében. — Földtudományi Szemle 1/2000, 8084.

SzePesi, J., ÉsIK, Zs., Novák, T. \& HARANGI, Sz. 2015: Hidden volcanic geoheritage of an UNESCO World Heritage Site, Tokaj Wine Region, Historic Cultural Landscape Hungary. - $2^{\text {nd }}$ Volcandpark Conference, Lanzarote Abstract Book, 35-36.

Szepesi, J., Harangi, Sz., Ésik, Zs., NováK, T., LuKÁcs, R. \& Soós, I. 2017: Volcanic Geoheritage and Geotourism Perspectives in Hungary: a Case of an UNESCO World Heritage Site, Tokaj Wine Region Historic Cultural Landscape, Hungary. — Geoheritage 8/27, 1-21. https://doi.org/10.1007/s12371-016-0205-0

SzonTAGH T. 1914: A természeti ritkaságok és szépségek védelme, gondozása. — Nemzeti Park — III. Állam-és jogtud. tanf. elốadásai 565-572.

TARDY J. (szerk.) 1996: Magyarországi települések védett természeti értékei. —Mezógazda Kiadó 663 p.

TARDY J. \& ORAVECZ I. 1990: Sághegyi tanösvény. — Földtani Közlöny 120/1-2, 129-131.

TARDY J., T. DRASKOviTs Zs. \& SZARVAS I. 2006: A földtani és felszínalaktani értékek védelme Magyarországon — történeti áttekintés, tények és lehetőségek. - III. Magyar Földrajzi Konferencia tudományos közleményei, 1-16.

TASNÁDI KUBACSKA A. 1954: Természetvédelem hazánkban — Útmutató a TTIT előadói számára — TTIT 71, Budapest.

Višnić, T., Spasojević, B. \& Vujičı́́, M. D. 2016: The Potential for Geotourism Development on the Srem Loess Plateau Based on a Preliminary Geosite Assessment Model (GAM). — Geoheritage 8/2, 173-180. https://doi.org/10.1007/s12371-015-0149-9

Vujičić, M. D., Vasiljevic, D. E., Markovic, S. B., Hose, T. A., Lukic, T., Hadzic, O. \& Janicevic, S. 2011: Slankamen Villages Preliminary Geosite Assessment Model (GAM) and its Application on Fruska Gora Mountain, Potential Geotourism Destination of Serbia. - Acta Geographica Slovenica 51/2, 361-377. https://doi.org/10.3986/ags51303

Wimbledon, W. A. W., Benton, M. J., Bevins, R. E, Black, G. P., Bridgland, D. R., Cleal, C. J., Cooper, R. G. \& MaY, V. J. 1995: The development of a methodology for the selection of British geological sites for geoconservation: part 1. — Mod. Geol. 20, 159-202.

Wimbledon, W. A. W., Andersen, S., Cleal, C. J., Cowie, J. W., Erikstad, L., Gonggrijp, G. P., Johansson, C. E., Karis, L. O. \& SuOMINEN, V. 1999: Geological World Heritage: GEOSITES - a global comparative site inventory to enable prioritisation for conservation. - Memorie Descrittive della Carta Geologica d'Italia 54, 45-60.

Zouros, N. C. 2007: Geomorphosite assessment and management in protected areas of Greece, Case study of the Lesvos island — coastal geomorphosites. — Geographica Helvetica 62/3, 1-12. https://doi.org/10.5194/gh-62-169-2007

1996. évi LIII. törvény a természet védelméról. - Magyar Közlöny 53, 3325-3346.

13/1997. (V.28.) KTM rendelet a védett természeti területek és értékek nyilvántartásáról.

55/2015 FM rendelet földtani alapszelvények és földtani képződmények védetté nyilvánításáról és természetvédelmi kezelési tervéről. www.globalgeopark.org, www.europeangeoparks.org, www.termeszetvedelem.hu

www.tajertektar.hu, www.kerettanterv.ofi.hu

Kézirat beérkezett: 2017. 05. 03. 